\title{
Dertigers op de arbeidsmarkt : de bepaling van lange termijn effecten van onderwijs met behulp van een koppeling tussen het SLVO en het Sociaal Statistisch Bestand
}

Citation for published version (APA):

Traag, T., van der Valk, J., de Vries, M. R., \& van der Velden, R. K. W. (2006). Dertigers op de arbeidsmarkt : de bepaling van lange termijn effecten van onderwijs met behulp van een koppeling tussen het SLVO en het Sociaal Statistisch Bestand. Researchcentrum voor Onderwijs en Arbeidsmarkt, Faculteit der Economische Wetenschappen. ROA Reports No. 2 https://doi.org/10.26481/umarep.2006002

Document status and date:

Published: 01/01/2006

DOI:

10.26481/umarep.2006002

Document Version:

Publisher's PDF, also known as Version of record

\section{Please check the document version of this publication:}

- A submitted manuscript is the version of the article upon submission and before peer-review. There can be important differences between the submitted version and the official published version of record. People interested in the research are advised to contact the author for the final version of the publication, or visit the DOI to the publisher's website.

- The final author version and the galley proof are versions of the publication after peer review.

- The final published version features the final layout of the paper including the volume, issue and page numbers.

Link to publication

\footnotetext{
General rights rights.

- You may freely distribute the URL identifying the publication in the public portal. please follow below link for the End User Agreement:

www.umlib.nl/taverne-license

Take down policy

If you believe that this document breaches copyright please contact us at:

repository@maastrichtuniversity.nl

providing details and we will investigate your claim.
}

Copyright and moral rights for the publications made accessible in the public portal are retained by the authors and/or other copyright owners and it is a condition of accessing publications that users recognise and abide by the legal requirements associated with these

- Users may download and print one copy of any publication from the public portal for the purpose of private study or research.

- You may not further distribute the material or use it for any profit-making activity or commercial gain

If the publication is distributed under the terms of Article 25fa of the Dutch Copyright Act, indicated by the "Taverne" license above, 


\section{Dertigers op de arbeidsmarkt}

De bepaling van lange termijn effecten van onderwijs met behulp van een koppeling tussen het SLVO en het Sociaal Statistisch Bestand

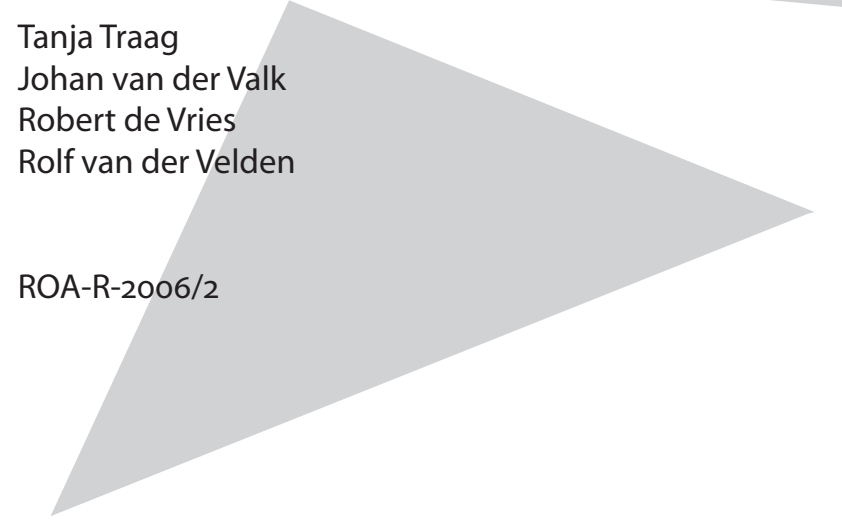

\section{Tanja Traag}

Johan van der Valk

Robert de Vries

Rolf van der Velden 


\section{Colofon}

(C) Researchcentrum voor Onderwijs en Arbeidsmarkt (ROA). Niets uit deze uitgave mag op enige manier worden verveelvoudigd zonder voorafgaande schriftelijke toestemming van de directeur van het ROA.

\section{Researchcentrum voor Onderwijs en Arbeidsmarkt}

Faculteit der Economische Wetenschappen en Bedrijfskunde

Universiteit Maastricht

\section{Vormgeving}

ROA secretariaat, Maastricht

\section{Verkoop}

Researchcentrum voor Onderwijs en Arbeidsmarkt

email: secretary@roa.unimaas.nl

website: www.roa.unimaas.nl

ISBN-IO: 90-532I-429-I

ISBN-I3: 978-90-532I-429-9

januari 2006

Dit onderzoek betreft een samenwerkingsproject tussen het CBS en het ROA in het kader van het strategisch onderzoeksprogramma Sociale Dynamiek en Arbeidsmarkt van het CBS. Het onderzoek kon tot stand komen dankzij een subsidie van het Ministerie van Onderwijs, Cultuur en Wetenschap en het Ministerie van Sociale Zaken en Werkgelegenheid.

医

Centraal Bureau voor de Statistiek

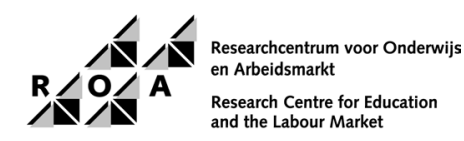




\section{Inhoud}

1 Inleiding 1

1.1 Inleiding 1

1.2 Achtergrond 2

1.3 Doelstelling 4

1.4 Opzet van dit rapport $\quad 5$

2 Datamateriaal: SLVO en SSB 7

2.1 Inleiding 7

2.2 Variabelen en operationalisaties $\quad 8$

3 Beschrijvende analyses $\quad 13$

$\begin{array}{lll}3.1 & \text { Inleiding } & 13\end{array}$

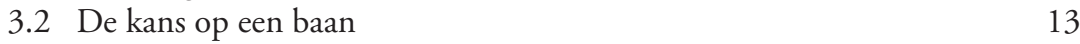

$\begin{array}{ll}3.3 \text { De positie in de werkkring } & 14\end{array}$

$\begin{array}{ll}3.4 \text { De inkomenspositie } & 18\end{array}$

4 Welke factoren bepalen de arbeidsmarktpositie van dertigers? 23

$\begin{array}{lll}4.1 & \text { Inleiding } & 23\end{array}$

4.2 Bereikt opleidingsniveau 24

4.3 De arbeidsmarktpositie van dertigers 26

5 Conclusie $\quad 35$

$6 \quad$ Literatuur $\quad 37$

Bijlage 1 Selectiviteit van de koppeling $\quad 39$

$\begin{array}{ll}\text { Bijlage 2 Operationalisering van de variabelen } & 41\end{array}$ 



\section{Inleiding}

\section{$1.1 \quad$ Inleiding}

De positie die mensen innemen op de arbeidsmarkt wordt tegenwoordig voor een belangrijk deel bepaald door het bereikte opleidingsniveau. Onderwijs vormt de sleutel tot interessant werk, een goed inkomen en een volwaardige sociale plek in de samenleving. In Nederland groeide vanaf de tweede helft van de vorige eeuw de wetenschappelijke interesse naar de achtergronden van schoolprestaties van leerlingen. Daarbij richtte de onderwijssociologie zich vooral op de vraag in hoeverre leerlingen met een verschillende achtergrond gelijke onderwijskansen hebben. In moderne samenlevingen zou iedereen gelijke toegang tot het onderwijs hebben, maar het bleek dat sociale herkomst een belangrijke rol speelt bij de schoolprestaties van leerlingen en zodoende van invloed is op de arbeidsmarktpositie die schoolverlaters weten te verwerven.

Schoolloopbaanonderzoek van het CBS, zoals het SMVO'77, SLVo'82 en later het VOCL'89 en vocL'93, waarbij grote groepen leerlingen voor een langere periode worden gevolgd zijn bij uitstek geschikt om de rol die het sociaal milieu van de ouders speelt bij de schoolprestaties van leerlingen te analyseren. Deze onderwijscohorten bevatten naast informatie over de schoolloopbaan relevante achtergrondinformatie over de leerlingen en de ouders. Aan de hand hiervan kan worden bepaald in hoeverre het bereikte opleidingsniveau van leerlingen kan worden toegeschreven aan het milieu van herkomst en cognitief vermogen. In deze rapportage wordt de rol van het bereikte opleidingsniveau, sociale herkomst en cognitief vermogen op de positie die werknemers verwerven op de arbeidsmarkt onderzocht. Dit is mogelijk omdat sinds kort op individueel niveau een koppeling is gelegd tussen het SLVO ${ }^{\mathrm{I}}$ en het Sociaal Statistisch Bestand (SSB). Het SLVO betreft een grootschalig onderwijscohort dat is gestart in 1982 en betreft leerlingen die in het laatste jaar van het basisonderwijs zaten. Deze leerlingen hebben ondertussen de leeftijdsfase bereikt waarbij een stabilisering van de loopbaan optreedt (33 jaar). Het ssв bevat gegevens over alle personen, banen en uitkeringen in Nederland die op micro-niveau aan elkaar relateerbaar zijn. In het ssB is onder meer informatie voorhanden over de positie in de werkkring, persoonlijk bruto jaarloon, burgerlijke staat et. cetera. Op deze manier is er een unieke dataset ontstaan waarmee de lange termijn

I. Schoolloopbaan en herkomst van leerlingen bij het voortgezet onderwijs. 
effecten van het onderwijs en andere persoonskenmerken op de beroepsloopbaan van schoolverlaters in Nederland kunnen worden geanalyseerd.

Dit onderzoek betreft een samenwerkingsverband tussen het CBS en het Researchcentrum voor Onderwijs en Arbeidsmarkt (ROA), en valt binnen het strategisch onderzoeksprogramma Sociale Dynamiek en Arbeidsmarkt van het CBS. ${ }^{2}$ Het gezamenlijk CBS-ROA onderzoek bestaat uit een drietal deelprojecten:

1. Een onderzoek naar de korte termijn effecten van het onderwijs: transities en competenties.

2. Een onderzoek naar de lange termijn effecten van het onderwijs.

3. Versterking van de data infrastructuur.

Het eerste deelproject is reeds uitgevoerd. In het rapport Leren Loont! De overgang van school naar werk voor leerlingen van het VOCL ' 89 (Traag et. al., 2004) is hiervan verslag gedaan. De resultaten van het tweede deelproject - de lange termijn effecten van het onderwijs - worden beschreven in dit rapport.

\subsection{Achtergrond}

Omdat onderwijs een belangrijke rol speelt bij de positie die mensen weten te verwerven op de arbeidsmarkt, is het van belang beter inzicht te krijgen in de achterliggende factoren die verklaren waarom de gevolgde opleiding zo'n belangrijke voorspeller is voor het latere arbeidsmarktsucces. Deze rol verschilt echter voor de onderscheiden periode in de beroepsloopbaan (zie Allen et al., 2000). Bij de transitie fase gaat het vooral om de vraag of de opleiding mensen voldoende startbekwaam heeft gemaakt. Dit uit zich vooral in een effect van specifieke kennis en vaardigheden. Voor de lange termijn zijn echter meer generieke competenties van belang om de 'employability' van afgestudeerden te verzekeren. De huidige schoolverlatersonderzoeken meten de opbrengst van opleidingen slechts op korte termijn (maximaal twee jaar na het verlaten van de opleiding). Daarmee kunnen opleidingen wel beoordeeld worden op de vraag of ze hun afgestudeerden voldoende 'startbekwaam' hebben gemaakt voor de arbeidsmarkt, maar niet of ze ook een voldoende basis hebben gegeven voor de verdere ontwikkeling en loopbaan van de afgestudeerden. Verbreding naar loopbaanonderzoek is hiervoor noodzakelijk.

In Nederland is op basis van verschillende longitudinale cohortonderzoeken onderzoek verricht naar de invloed van opleidingsniveau, sociale herkomst en schoolprestaties op de positie die personen verwerven op de arbeidsmarkt. Zo is in het schooljaar 1964/65 gestart met het 'Van Jaar Tot Jaar'-cohort (Collaris \& Kropman, 1978; Diederen, 199I), dat tot ver in de jaren tachtig is gevolgd op de arbeidsmarkt. In

2. Het strategisch onderzoeksprogramma Sociale dynamiek en arbeidsmarkt van het CBS ontwikkelt samen met andere kennisinstituten statistische informatie op het terrein van arbeidsmarkt-, inkomensen huishoudensdynamiek. Voor meer informatie: http://www.cbs.nl/nl/service/ onderzoek/strat-ondz/ index.htm. 
I977 is gestart met het SMVO-cohort, waarin de school- en beroepsloopbanen van een generatie Nederlandse jongeren is vastgelegd (Meesters, 1992). Daarnaast bestaat er ook een aantal regionale cohorten, zoals het Noord-Brabant-cohort, dat is gestart in 1952. Dit cohort is op verschillende tijdstippen gedurende de onderwijs- en beroepsloopbaan (opnieuw) benaderd (Dronkers, 1987; Hartog \& Pfann, 1985; Meesters, Dronkers \& Schijf, 1983). Verder is in 1965 begonnen met het zogenaamde Enschedecohort, dat begin jaren negentig opnieuw is benaderd (Bros \& Dronkers, 1994). Het opnieuw tot leven wekken van grootschalige cohorten is dus niet nieuw. Echter, met het beschikbaar komen van longitudinaal gekoppelde informatie uit gemeentelijke administraties en integrale informatie over arbeidsmarktkenmerken is de representativiteit van herbenaderde steekproeven verbeterd en liggen de kosten lager. Vroeger was men meer afhankelijk van adresgegevens en de bereidwilligheid van respondenten, waardoor vaak de populatie nog maar een klein deel van het oorspronkelijke cohort bevatte. Bovendien zijn in het stvo over het algemeen betere metingen beschikbaar van alle cruciale variabelen dan in eerder onderzoek gebruikte gegevens, bijvoorbeeld als het gaat om de meting van schoolprestaties die in het sLvo gebaseerd zijn op nationaal gestandaardiseerde toetsen van het CITO. Een nadeel van het sLvo is dat de onderwijsloopbaan van de leerlingen is gevolgd tot het moment dat ze het voltijd onderwijs voor de eerste keer hebben verlaten. Dit houdt in dat er geen informatie voorhanden is over eventuele onderwijsdeelname na het verlaten van het voltijd onderwijs.

Met de start van SMvo (vocL'77) en SLvo (vocL'82) is de representativiteit en kwaliteit van de Nederlandse onderwijscohorten geweldig verbeterd. De betreffende cohorten bevatten een schat aan relevante achtergrondinformatie van de respondenten (thuissituatie, leerprestaties, schoolloopbaan etcetera). Sinds kort is op individueel niveau een koppeling gelegd tussen het sLvo en het Sociaal Statistisch Bestand. Met behulp van de informatie uit het Sociaal Statistisch Bestand kan de huidige positie van de leerlingen van het sLvo in kaart wordt gebracht. Deze leerlingen hebben ondertussen de leeftijdsfase bereikt waarbij een stabilisering van de loopbaan optreedt (33 jaar). Dit stelt ons beter dan in eerder verricht onderzoek in staat de lange termijn effecten van onderwijs op de arbeidsmarktpositie van schoolverlaters in Nederland vast te stellen.

Dit rapport geeft antwoord op de volgende vragen:

- Wat zijn de lange termijn effecten van de gevolgde opleiding op de huidige arbeidsmarktpositie?

- Wat is de invloed van sociale en culturele hulpbronnen op de bereikte arbeidsmarktpositie?

- Wat is de invloed van cognitief vermogen op de bereikte arbeidsmarktpositie?

Om deze vragen te beantwoorden wordt onderzocht in hoeverre de arbeidsmarktpositie van oud-leerlingen van het sLvo wordt bepaald door het bereikte opleidingsniveau, sociale herkomst en cognitief vermogen. In figuur I.I is dit schematisch weergegeven. Uitgangspunt is de positie van leerlingen op I2-jarige leeftijd, wanneer ze in het laatste jaar van het basisonderwijs zitten. Van deze leerlingen is informatie 
aanwezig over de sociale herkomst en de thuissituatie (etniciteit, opleidingsniveau ouders, maatschappelijke positie ouders, en onderwijsondersteunend thuisklimaat). Daarnaast is er informatie over het cognitief vermogen (schoolprestaties, non-verbale intelligentie, leesgedrag en schooladvies). Aan de hand hiervan wordt onderzocht in hoeverre sociale herkomst en cognitief vermogen, gemeten op I2-jarige leeftijd, van invloed zijn op het opleidingsniveau dat de leerlingen uiteindelijk hebben bereikt (I). Vervolgens verlaten de leerlingen het onderwijs. Met behulp van gegevens van het ssB is er informatie voorhanden over de arbeidsmarktpositie op 33-jarige leeftijd. Met behulp hiervan wordt onderzocht in welke mate het bereikte opleidingsniveau van invloed is op de arbeidsmarktpositie op 33-jarige leeftijd (2). Daarnaast wordt bepaald in hoeverre sociale herkomst en cognitief vermogen, los van het behaalde opleidingsniveau, van invloed zijn op de arbeidsmarktpositie (3).

Figuur 1.1

De lange termijn effecten van onderwijs op de arbeidsmarktpositie van dertigers

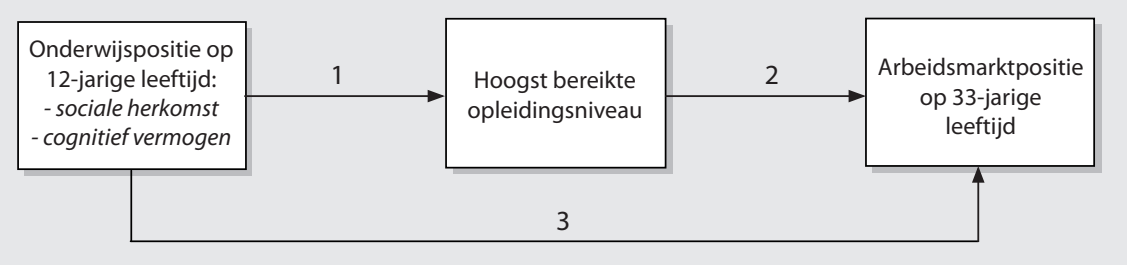

\subsection{Doelstelling}

Het thema Sociale dynamiek en arbeidsmarkt heeft als doel het ontwikkelen van nieuwe, geïntegreerde, samenhangende statistische persoonsinformatie over de arbeidsmarkt-, huishouden-, inkomen- en vermogensdynamiek. Met geïntegreerde persoonsinformatie wordt bedoeld dat statistieken tot stand komen door het samenvoegen van informatie uit díe bronnen die de informatie het beste bevatten. Integratie houdt echter ook in dat, bij discrepanties tussen definities in bronnen de beste wordt bepaald, zodat er overeenstemming wordt bereikt over de te gebruiken definitie. Op deze wijze wordt beoogd de transities die individuen gedurende hun verblijf op de arbeidsmarkt maken inzichtelijk te krijgen. Eén van de transities die in dit proces van cruciaal belang zijn, is de transitie van het onderwijs naar de arbeidsmarkt. Bovendien beoogt het CBS het verwerven van de benodigde kennis om zo efficiënt mogelijk gebruik te maken van verschillende bronnen en het integreren van deze bronnen in het loopbaanonderzoek.

Het samenwerkingsproject richt zich op de transitie van het onderwijs naar de arbeidsmarkt. Een gezamenlijke doelstelling van het CBS en het ROA is in de eerste plaats het verkrijgen van inzicht in de effecten van onderwijs, competenties en sociale en culturele hulpbronnen op de arbeidsmarktloopbaan. In de tweede plaats beogen beide instituten de statistische informatie van de transitie van onderwijs naar arbeidsmarkt te verbeteren. Het derde doel is het verwerven van kennis over relevante indica- 
toren dat zal bijdragen aan het zo efficiënt mogelijk uitvoeren van schoolloopbaan- en schoolverlatersonderzoek.

\subsection{Opzet van dit rapport}

De opbouw van dit rapport is als volgt. In hoofdstuk 2 worden de data besproken die voor de analyses zijn gebruikt: het sLvo en het ssB. Daarbij wordt beschreven hoe de verschillende variabelen zijn geoperationaliseerd. In hoofdstuk 3 vinden de beschrijvende analyses plaats. Hiertoe wordt voor de oud-leerlingen van het SLvo van verschillend opleidingsniveau en -richting de arbeidsmarktpositie bepaald. Dit wordt gedaan voor een drietal arbeidsmarktkenmerken, de kans op een baan, de positie in de werkkring en het inkomen. Deze analyses worden apart voor mannen en vrouwen uitgevoerd. Vervolgens komen in hoofdstuk 4 de verklarende analyses aan bod. Onderzocht wordt welke kenmerken naast het bereikte opleidingsniveau en de gevolgde opleidingsrichting van invloed zijn op de arbeidsmarktpositie van oud-leerlingen van het sLvo. Daarbij ligt de nadruk op sociale en culturele hulpbronnen en cognitief vermogen. Ook deze analyses worden apart voor mannen en vrouwen uitgevoerd. Tot slot volgen in hoofdstuk 5 de conclusies en aanbevelingen voor verder onderzoek naar de lange termijn effecten van onderwijs op de arbeidsmarktpositie van personen. 



\section{Datamateriaal: SLVO en SSB}

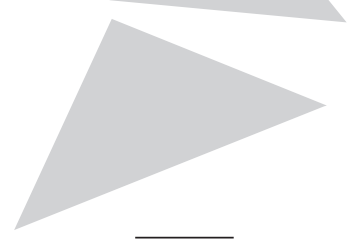

\subsection{Inleiding}

Voor de analyses in dit rapport zijn gegevens gebruikt uit twee databestanden: Schoolloopbaan en herkomst van leerlingen bij het voorgezet onderwijs I982 (sLVo) en het Sociaal Statistisch Bestand (ssB).

Het SLVo is een grootschalig onderwijscohort die is gestart in 1982 met een groep van I6.8I3 leerlingen die in het laatste jaar van het basisonderwijs zaten. Van deze leerlingen is sindsdien de onderwijsloopbaan gevolgd tot het moment dat ze het voltijd onderwijs voor de eerste keer hebben verlaten respectievelijk tot de leeftijd van ongeveer 29 jaar. Dit houdt onder meer in dat jaarlijks wordt vastgesteld in welk leerjaar van welk schooltype de leerlingen zitten. Daarnaast zijn testen afgenomen met betrekking tot schoolprestaties en non-verbale intelligentie. Bovendien is bij de start van het onderzoek een schriftelijke vragenlijst afgenomen bij de ouders van de leerlingen met als doel om informatie over gezins- en leerlingkenmerken te verzamelen. In grote lijnen kan de steekproef als representatief worden beschouwd voor alle leerlingen die in het schooljaar I98I/1982 in het laatste jaar van het basisonderwijs zaten.

In dit rapport is informatie uit het SSB van het jaar 2003 opgenomen. Het SSB bevat gegevens over alle personen, banen en uitkeringen in Nederland die op micro-niveau aan elkaar relateerbaar zijn. Eind jaren '9o van de vorige eeuw is het CBs begonnen met het ontwikkelen hiervan. Voor de koppeling tussen het SLVo en het SSB is eerst een koppeling gemaakt tussen het suvo met de Gemeentelijke Basis Administratie (GBA). Het doel van deze koppeling is het voorzien van leerlingen van het onderwijscohort van een rinpersoonsnummer ${ }^{\mathrm{I}}$ om koppeling met het SSB mogelijk te maken. Vervolgens kan op deze manier de initiële onderwijsloopbaan aan worden gevuld met arbeidsmarkt- en persoonskenmerken uit het ssв. Op deze manier is voor de cohortleerlingen van het sLvo cohort informatie over de positie in de werkkring, persoonlijk bruto jaarloon, burgerlijke staat etcetera voorhanden. Niet iedereen uit het SLVO cohort kon worden gekoppeld aan het ssB. In totaal is ongeveer $88 \%$ van de personen

I. Voor het koppelen van steekproefgegevens aan het SSB is een rinpersoonsnummer nodig. Dit rinpersoonsnummer wordt verkregen door een koppeling te leggen met het sofinummer. Voor deze koppeling is gedetailleerde informatie over een persoon nodig in de vorm van NAw-gegevens en/of geboortedata. Het sLvo is in het najaar van 2004 voorzien van rinpersoonsnummers om een koppeling met het ssB mogelijk te maken. 
uit het SLvo cohort voorzien van een rinpersoonsnummer. Er is nagegaan in hoeverre de koppeling tussen het SLVO en het ssB leidt tot selectiviteit binnen de onderzoekspopulatie. Hiervoor is de gekoppelde populatie vergeleken met de oorspronkelijke steekproef voor een aantal kenmerken: geslacht, schooladvies, hoogst behaald opleidingsniveau, sociaal milieu en het opleidingsniveau van de vader en de moeder. De desbetreffende tabellen staan weergegeven in bijlage I. Voor geen van de opgenomen kenmerken bleek er een significant verschil te zijn tussen de oorspronkelijke steekproef van het sLvo en de groep die gekoppeld kon worden met het ssB. De in deze analyses gebruikte onderzoekspopulatie kan dus beschouwd worden als een goede afspiegeling van de oorspronkelijke steekproef.

\subsection{Variabelen en operationalisaties}

In deze paragraaf wordt beschreven welke operationalisaties zijn gebruikt en hoe de univariate verdelingen van de gebruikte variabelen eruit zien. Een uitgebreide beschrijving van de variabelen is bijgevoegd in bijlage 2 . In tabel 2-I is een statistisch overzicht weergegeven van de variabelen die zijn gebruikt in de analyses.

SLVO

Het hoogst bereikte opleidingsniveau is het met diploma afgesloten niveau op het moment dat de leerlingen het voltijd onderwijs (voor de eerste keer) verlaten. Het niveau is vastgesteld op basis van de leerjarenladder (zie bijlage 2). De opleidingsrichting verwijst ook naar de met een diploma afgesloten hoogst bereikte opleiding op het moment dat de leerlingen het voltijd onderwijs (voor de eerste keer) verlaten. Deze is ingedeeld in zes categorieën (zie bijlage 2). Etniciteit is onderverdeeld in allochtonen en autochtonen.

De cognitieve vaardigheden van de oud-leerlingen uit het sLvo cohort zijn gemeten in drie variabelen; het leesgedrag van de leerling, de schoolprestaties en de non-verbale intelligentie. Deze zijn gemeten in het laatste jaar van het basisonderwijs. Het leesgedrag is gemeten aan de hand van het aantal uren per week dat leerlingen volgens de ouders besteden aan het lezen van boeken en kranten. De schoolprestaties zijn gemeten aan de hand van drie afzonderlijke deeltoetsen: Nederlands, rekenen en informatieverwerking. De scores van de afzonderlijke toetsen zijn samengevoegd tot één totaalscore. De intelligentietoets bestond uit twee onderdelen: een subtest voor het redeneervermogen en een subtest voor het abstractievermogen. Ook deze twee subtesten zijn samengevoegd tot één meting van de non-verbale intelligentie.

De ouderlijke hulpbronnen zijn gemeten in een aantal kenmerken: het opleidingsniveau van de ouders, de maatschappelijke positie van de ouders en het onderwijsondersteunende thuisklimaat. De ouderkenmerken zijn gemeten via een vragenlijst aan de ouders die in het laatste leerjaar van het basisonderwijs aan de leerlingen mee 
naar huis is gegeven. Het opleidingsniveau van de ouders is bepaald aan de hand van het gemiddelde opleidingsniveau van de ouders. De maatschappelijke positie van de ouders is gemeten aan de hand van informatie over de werkzaamheid en het beroep van de hoofdkostwinner van het gezin. Het onderwijsondersteunende thuisklimaat zegt iets over de interesse die de ouders uiten voor de schoolprestaties van hun kind en het welbevinden op school.

\section{Tabel 2-1}

Statistische beschrijving van de gebruikte variabelen, mannen

\begin{tabular}{|c|c|c|c|c|c|c|}
\hline & Gemiddelde & $\begin{array}{l}\text { Standaard- } \\
\text { Afwijking }\end{array}$ & Percentage & Minimum & Maximum & $\mathrm{N}$ \\
\hline Opleidingsniveau & 12,47 & 3,61 & & 6 & 19 & 7,225 \\
\hline \multicolumn{7}{|l|}{ Opleidingsrichting } \\
\hline Algemeen & & & 31,4 & & & 7,225 \\
\hline Landbouw & & & 7,0 & & & 7,225 \\
\hline Techniek & & & 36,2 & & & 7,225 \\
\hline Economie & & & 1,8 & & & 7,225 \\
\hline Gezondheidszorg & & & 17,2 & & & 7,225 \\
\hline Overig & & & 6,3 & & & 7,225 \\
\hline \multicolumn{7}{|l|}{ Etniciteit } \\
\hline Autochtoon & & & 91,0 & & & 7,225 \\
\hline Allochtoon & & & 9,0 & & & 7,225 \\
\hline Opleidingsniveau ouders & 9,77 & 3,27 & & 6 & 19 & 6,671 \\
\hline \multicolumn{7}{|l|}{ Maatschappelijke positie ouders } \\
\hline Niet werkzaam & & & 14,2 & & & 6,547 \\
\hline Arbeider & & & 32,9 & & & 6,547 \\
\hline Zelfstandige zonder personeel & & & 6,8 & & & 6,547 \\
\hline Zelfstandige met personeel & & & 4,6 & & & 6,547 \\
\hline Lagere employee & & & 11,8 & & & 6,547 \\
\hline Middelbare employee & & & 18,0 & & & 6,547 \\
\hline Hogere employee & & & 11,7 & & & 6,547 \\
\hline Schoolprestaties & 0,51 & 0,29 & & 0 & 1 & 7,133 \\
\hline Non-verbale intelligentie & 0,49 & 0,24 & & 0 & 1 & 7,174 \\
\hline Schooladvies & 7,12 & 1,07 & & 5 & 9 & 7,107 \\
\hline Leesgedrag leerling & 2,90 & 0,96 & & 1 & 5 & 6,662 \\
\hline Onderwijsondersteunend thuisklimaat & 0,51 & 0,29 & & 0 & 1 & 6,684 \\
\hline \multicolumn{7}{|l|}{ Positie in de werkkring } \\
\hline Werknemer & & & 79,1 & & & 7,225 \\
\hline Zelfstandige & & & 7,7 & & & 7,225 \\
\hline Uitkering & & & 4,1 & & & 7,225 \\
\hline Geen inkomensbron & & & 3,8 & & & 7,225 \\
\hline Gemengde groep & & & 5,3 & & & 7,225 \\
\hline Betaalde baan & & & 91,5 & & & 7,225 \\
\hline Gemiddeld inkomen per sv-dag & 127,40 & 43,31 & & 13,08 & 335,80 & 5,996 \\
\hline
\end{tabular}

Bron: Schoolloopbaan en herkomst van leerlingen bij het voorgezet onderwijs (SLVO) 1982, Sociaal Statistisch Bestand (SSB), Centraal Bureau voor de Statistiek 
Schooladvies verwijst naar het schooladvies dat de leerling kreeg in het laatste jaar van de basisschool met betrekking tot de doorstoom naar het voortgezet onderwijs. Dit advies is gecodeerd op basis van de leerjarenladder (zie Bijlage 2).

Tabel 2-2

Statistische beschrijving van de gebruikte variabelen, vrouwen

\begin{tabular}{|c|c|c|c|c|c|c|}
\hline & Gemiddelde & $\begin{array}{l}\text { Standaard- } \\
\text { Afwijking }\end{array}$ & Percentage & Minimum & Maximum & N \\
\hline Opleidingsniveau & 12,57 & 3,37 & & 6 & 19 & 7,342 \\
\hline Opleidingsrichting & & & & & & 7,342 \\
\hline Algemeen & & & 38,8 & & & 7,342 \\
\hline Landbouw & & & 2,4 & & & 7,342 \\
\hline Techniek & & & 4,4 & & & 7,342 \\
\hline Economie & & & 15,2 & & & 7,342 \\
\hline Gezondheidszorg & & & 28,4 & & & 7,342 \\
\hline Overig & & & 10,7 & & & 7,342 \\
\hline \multicolumn{7}{|l|}{ Etniciteit } \\
\hline Autochtoon & & & 91,3 & & & 7,342 \\
\hline Allochtoon & & & 8,7 & & & 7,342 \\
\hline Opleidingsniveau ouders & 9,70 & 3,29 & & 6 & 19 & 6,782 \\
\hline Maatschappelijke positie ouders & & & & & & 6,694 \\
\hline Niet werkzaam & & & 15,7 & & & 6,694 \\
\hline Arbeider & & & 31,3 & & & 6,694 \\
\hline Zelfstandige zonder personeel & & & 6,0 & & & 6,694 \\
\hline Zelfstandige met personeel & & & 4,9 & & & 6,694 \\
\hline Lagere employee & & & 12,2 & & & 6,694 \\
\hline Middelbare employee & & & 18,4 & & & 6,694 \\
\hline Hogere employee & & & 11,5 & & & 6,694 \\
\hline Schoolprestaties & 0,49 & 0,28 & & 0 & 1 & 7,238 \\
\hline Non-verbale intelligentie & 0,51 & 0,24 & & 0 & 1 & 7,266 \\
\hline Schooladvies & 7,25 & 1,02 & & 5 & 9 & 7,230 \\
\hline Leesgedrag leerling & 3,15 & 0,91 & & 1 & 5 & 7,686 \\
\hline Onderwijsondersteunend thuisklimaat & 0,49 & 0,28 & & 0 & 1 & 6,813 \\
\hline \multicolumn{7}{|l|}{ Positie in de werkkring } \\
\hline Werknemer & & & 70,1 & & & 7,342 \\
\hline Zelfstandige & & & 3,8 & & & 7,342 \\
\hline Uitkering & & & 6,6 & & & 7,342 \\
\hline Geen inkomensbron & & & 13,7 & & & 7,342 \\
\hline Gemengde groep & & & 5,8 & & & 7,342 \\
\hline Betaalde baan & & & 78,7 & & & 7,342 \\
\hline Gemiddeld inkomen per sv-dag & 101,0 & 44,04 & & 12,61 & 335,07 & 5,445 \\
\hline
\end{tabular}

Bron: Schoolloopbaan en herkomst van leerlingen bij het voorgezet onderwijs (SLVO) 1982, Sociaal Statistisch Bestand (SSB), Centraal Bureau voor de Statistiek 
De variabele betaalde baan maakt een onderscheid tussen degenen met tenminste één baan en degenen zonder een baan. De positie in de werkkring is onderverdeeld in vijf categorieën I) werknemer, 2) zelfstandige, 3) uitkering, 4) geen inkomensbron en 5) gemengde groep. De gemengde groep bestaat uit degenen met een combinatie van werknemer en zelfstandige, werknemer en uitkering, zelfstandige en uitkering of werknemer, zelfstandige en uitkering (inclusief pensioen).

De beloning is gebaseerd op het gemiddeld inkomen per sociale verzekeringsdag. Hiervoor is het bruto jaarloon sociale verzekering gedeeld door het aantal sociale verzekeringsdagen. Het bruto loon sociale verzekering is het loon waarover premieheffing voor de werknemersverzekeringen plaats vindt. De sociale verzekeringsdagen (sv-dagen) zijn het aantal werkdagen waarover premieheffing voor de werknemersverzekeringen plaats vindt. Ook als slechts één uur op een dag wordt gewerkt, wordt deze dag als één sv-dag meegeteld. Bij de bepaling van de beloning zijn personen met de positie zelfstandige niet meegenomen. 



\section{Beschrijvende analyses}

\subsection{Inleiding}

In dit hoofdstuk wordt de arbeidsmarktpositie van voormalige leerlingen van het SLVO-cohort in 2003 beschreven, als deze personen gemiddeld 33 jaar oud zijn. Dit wordt uitgesplitst naar opleidingsniveau en opleidingssector. De volgende kenmerken komen aan bod: de kans op een baan, de positie in de werkkring en het inkomen. Het gaat hier om kruistabellen, dat wil zeggen om bivariate effecten zonder dat er gecontroleerd wordt voor andere persoonskenmerken.

\subsection{De kans op een baan}

Figuur 3.I laat de kans op werk zien voor mannen. Vermeld is het aandeel mannen met tenminste één baan. Hieruit blijkt dat het overgrote deel van de mannen minstens één baan heeft. Opvallend is echter de relatief kleine kans op werk voor mannen met als hoogst behaalde opleiding basisonderwijs. Slechts $86 \%$ van de mannen met uitsluitend basisonderwijs heeft minstens één baan. Bij de overige opleidingsniveaus varieert dit van $94 \%$ bij het MAvo tot $98 \%$ bij het wo. Op zich is dit laatste vrij opmerkelijk omdat dit aangeeft dat op de lange termijn de kans op werk voor degenen met een MAVO- of VBO-diploma vrijwel even groot is als voor degenen met een MBO, HBO- of wo-diploma. Daarnaast speelt de richting van gevolgde opleiding bij mannen nauwelijks een rol bij de kans op werk. Binnen de opleidingsniveaus bestaan er vrijwel geen verschillen in het aandeel mannen met tenminste één baan. Enige uitzondering zijn mannen van de richting overig; binnen alle opleidingsniveaus geldt dat degenen van de richting overig het minst vaak een baan hebben.

Uit figuur 3.2 blijkt dat ook vrouwen met uitsluitend basisonderwijs veruit de kleinste kans hebben op werk. Ongeveer driekwart van de vrouwen met als hoogst behaalde opleiding basisonderwijs hebben minstens één baan. Opvallend is hier dat ook vrouwen met het vво als hoogst behaalde opleiding een relatief kleine kans hebben op minstens één baan (84\%). Dit geldt voor alle opleidingsrichtingen binnen het vBO. Voor de overige opleidingsniveaus varieert het aandeel vrouwen met tenminste één baan van $91 \%$ bij het MAvo tot $97 \%$ bij het wo. Daarbij bestaan binnen de opleidingsniveaus vrij weinig verschillen naar richting in het aandeel vrouwen met minstens één baan. Alléén in het vво en мво hebben vrouwen van de richting overig minder vaak een baan. 
Figuur 3-1

De kans op het hebben van minstens één baan voor mannen

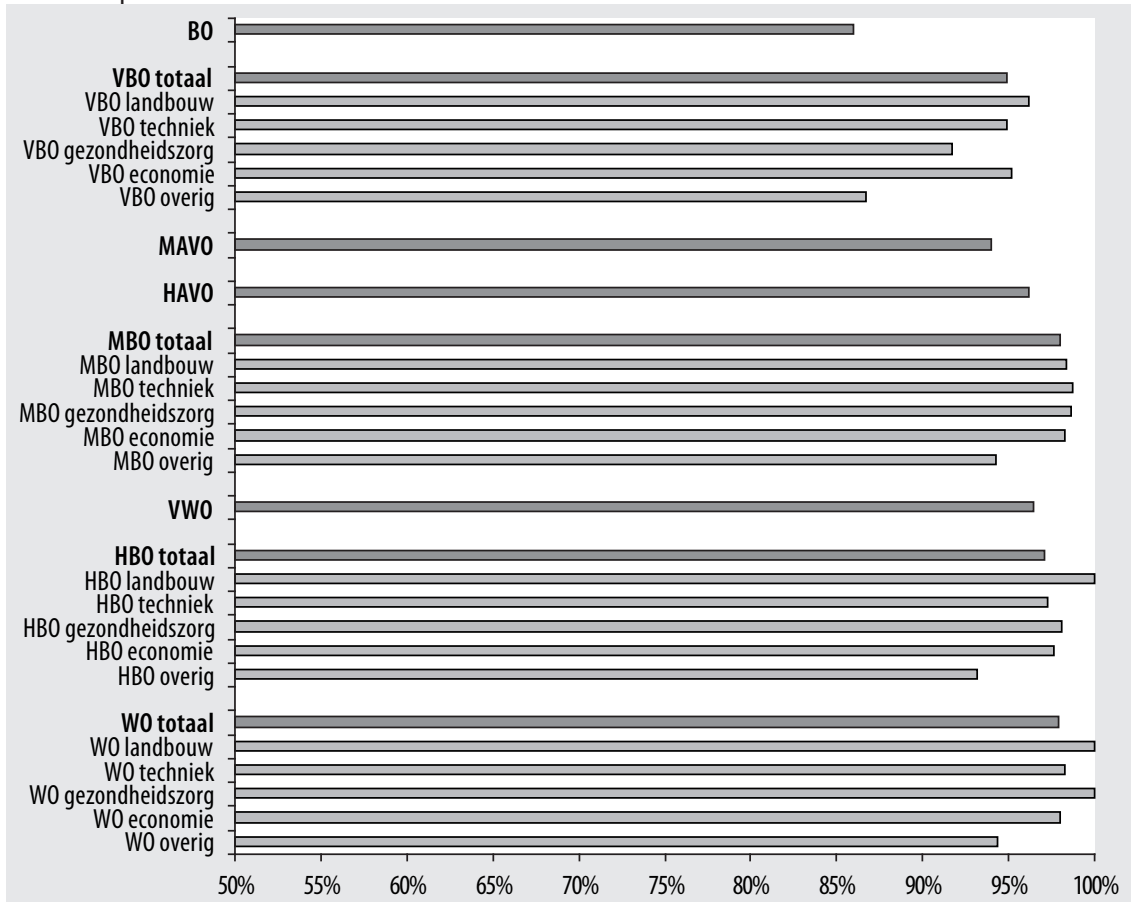

Bron: Schoolloopbaan en herkomst van leerlingen bij het voorgezet onderwijs (SLVO) 1982, Sociaal Statistisch Bestand (SSB), Centraal Bureau voor de Statistiek

Bovendien verschillen mannen en vrouwen enigszins in de kans op het hebben van een baan. Weliswaar is zowel bij mannen als vrouwen de kans op een baan veruit het kleinst voor degenen die uitsluitend basisonderwijs hebben behaald. Maar vrouwen met uitsluitend basisonderwijs hebben aanzienlijk minder vaak werk dan mannen met uitsluitend basisonderwijs. Bovendien hebbben mannen met een vво-diploma duidelijk vaker een baan dan vrouwen met een vво-diploma. Tussen mannen en vrouwen met een мво-, нво- of wо-diploma bestaan daarentegen vrijwel geen verschillen in de kans op werk.

\subsection{De positie in de werkkring}

Tabel 3.I vermeldt de positie in de werkkring van mannen. Hieruit komt naar voren dat bijna $80 \%$ van de mannen werknemer is. Daarbij neemt de kans om werknemer te zijn toe naarmate het opleidingsniveau stijgt. Van degenen die uitsluitend basisonderwijs hebben behaald is $66 \%$ werkzaam als werknemer. Voor de overige opleidingsniveaus varieert dit aandeel van 79\% bij MAVO en vBO tot ongeveer $85 \%$ bij HBO en wo. Ook tussen de opleidingsrichtingen bestaan duidelijke verschillen in het aandeel 
werknemers. Mannen die een opleiding in de richting landbouw hebben gevolgd zijn, met uitzondering van het wo, minder vaak werknemer dan mannen met een andere opleidingsrichting. Deze verschillen zijn vooral groot bij het мво. Binnen het мво is 'slechts' de helft met een opleiding in de richting landbouw werknemer, terwijl dit aandeel binnen het мво gemiddeld $80 \%$ is.

\section{Figuur 3-2}

De kans op het hebben van minstens één baan voor vrouwen

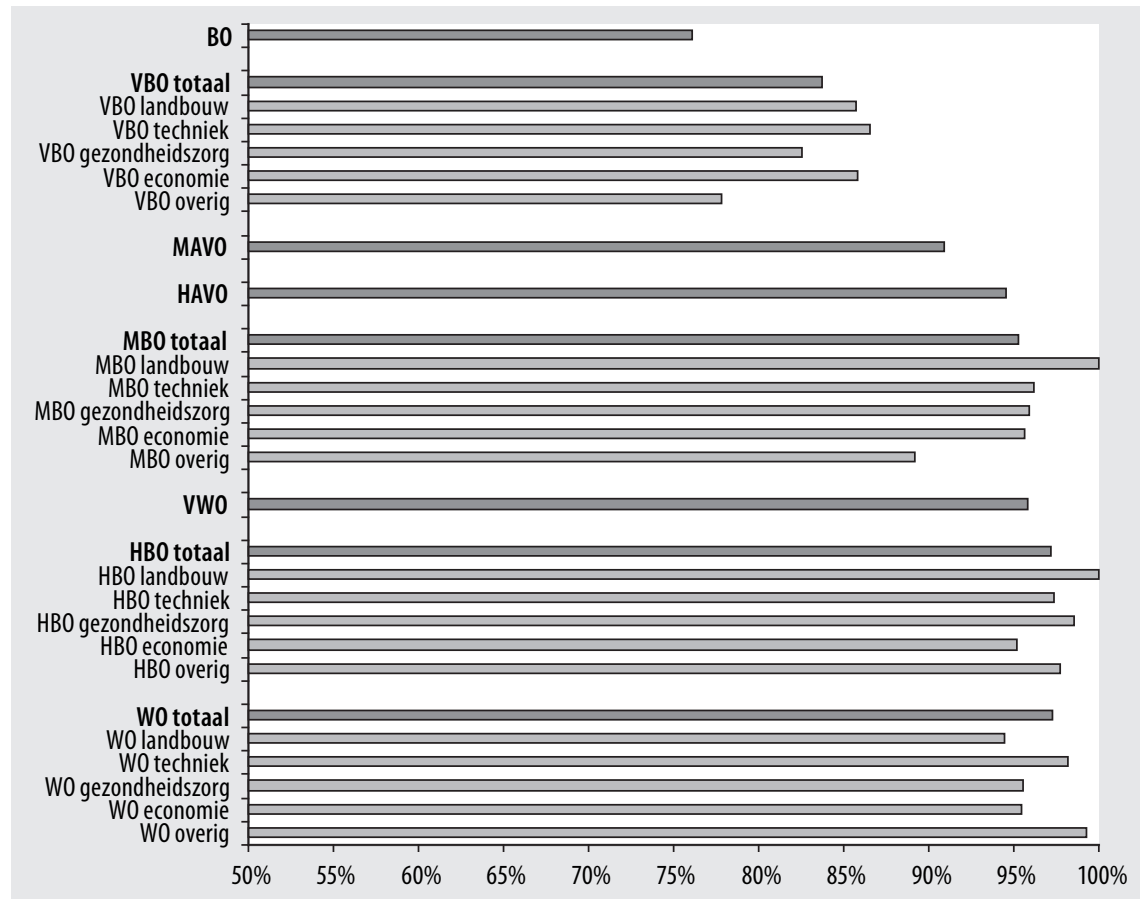

Bron: Schoolloopbaan en herkomst van leerlingen bij het voorgezet onderwijs (SLVO) 1982, Sociaal Statistisch Bestand (SSB), Centraal Bureau voor de Statistiek

Zelfstandigen komen relatief gezien vaker voor in de lagere opleidingsniveaus dan in de hogere. Ongeveer IO\% van degenen met het opleidingsniveau basisonderwijs, vво of мво is zelfstandige, terwijl bij het нво en wo dit circa $4 \%$ is. Zelfstandig ondernemerschap komt verder relatief vaak voor onder degenen met een landbouwopleiding. Dit is vooral duidelijk te zien bij het мво waar eenderde werkzaam is als zelfstandige. Eenzelfde patroon is te zien bij de gemengde groep, waar mensen meerdere vormen arbeidsmarktposities combineren. $\mathrm{Bij}$ мво landbouw en нво landbouw combineren mensen relatief vaak zelfstandig ondernemerschap met een andere inkomstenbron, vanwege de vaak sterk wisselende inkomsten uit de onderneming. 
Tabel 3-1

De positie in de werkkring voor mannen

\begin{tabular}{|c|c|c|c|c|c|}
\hline $\begin{array}{l}\text { Hoogst behaald } \\
\text { opleidingsniveau }\end{array}$ & Zelfstandige & Uitkering & $\begin{array}{c}\text { Geen } \\
\text { inkomstenbron }\end{array}$ & $\begin{array}{l}\text { Gemengde groep } \\
\text { incl. pensioen }\end{array}$ & Werknemer \\
\hline BO & $10 \%$ & $12 \%$ & $7 \%$ & $5 \%$ & $66 \%$ \\
\hline VBO totaal & $9 \%$ & $4 \%$ & $3 \%$ & $6 \%$ & $79 \%$ \\
\hline VBO landbouw & $16 \%$ & $4 \%$ & $1 \%$ & $5 \%$ & $73 \%$ \\
\hline VBO techniek & $7 \%$ & $4 \%$ & $3 \%$ & $6 \%$ & $80 \%$ \\
\hline VBO gezondheidszorg & $16 \%$ & $4 \%$ & $4 \%$ & $4 \%$ & $72 \%$ \\
\hline VBO economie & $9 \%$ & $5 \%$ & $3 \%$ & $5 \%$ & $78 \%$ \\
\hline VBO overig & $13 \%$ & $13 \%$ & $0 \%$ & $20 \%$ & $53 \%$ \\
\hline MAVO & $7 \%$ & $5 \%$ & $4 \%$ & $5 \%$ & $79 \%$ \\
\hline HAVO & $8 \%$ & $3 \%$ & $4 \%$ & $3 \%$ & $81 \%$ \\
\hline MBO totaal & $10 \%$ & $1 \%$ & $2 \%$ & $6 \%$ & $80 \%$ \\
\hline MBO landbouw & $32 \%$ & $0 \%$ & $2 \%$ & $15 \%$ & $51 \%$ \\
\hline MBO techniek & $7 \%$ & $1 \%$ & $1 \%$ & $4 \%$ & $87 \%$ \\
\hline MBO gezondheidszorg & $7 \%$ & $0 \%$ & $1 \%$ & $5 \%$ & $86 \%$ \\
\hline MBO economie & $7 \%$ & $2 \%$ & $3 \%$ & $4 \%$ & $84 \%$ \\
\hline MBO overig & $6 \%$ & $4 \%$ & $4 \%$ & $5 \%$ & $82 \%$ \\
\hline vwo & $4 \%$ & $3 \%$ & $7 \%$ & $6 \%$ & $81 \%$ \\
\hline HBO totaal & $4 \%$ & $2 \%$ & $4 \%$ & $5 \%$ & $85 \%$ \\
\hline HBO landbouw & $15 \%$ & $0 \%$ & $1 \%$ & $10 \%$ & $74 \%$ \\
\hline HBO techniek & $2 \%$ & $2 \%$ & $3 \%$ & $4 \%$ & $89 \%$ \\
\hline HBO gezondheidszorg & $7 \%$ & $2 \%$ & $9 \%$ & $2 \%$ & $81 \%$ \\
\hline HBO economie & $2 \%$ & $2 \%$ & $4 \%$ & $4 \%$ & $88 \%$ \\
\hline $\mathrm{HBO}$ overig & $10 \%$ & $5 \%$ & $3 \%$ & $7 \%$ & $75 \%$ \\
\hline W0 totaal & $3 \%$ & $2 \%$ & $6 \%$ & $5 \%$ & $84 \%$ \\
\hline WO landbouw & $6 \%$ & $0 \%$ & $0 \%$ & $0 \%$ & $94 \%$ \\
\hline W0 techniek & $3 \%$ & $2 \%$ & $7 \%$ & $6 \%$ & $82 \%$ \\
\hline W0 gezondheidszorg & $4 \%$ & $0 \%$ & $4 \%$ & $8 \%$ & $83 \%$ \\
\hline WO economie & $3 \%$ & $1 \%$ & $5 \%$ & $2 \%$ & $89 \%$ \\
\hline W0 overig & $2 \%$ & $5 \%$ & $13 \%$ & $8 \%$ & $72 \%$ \\
\hline
\end{tabular}

Bron: Schoolloopbaan en herkomst van leerlingen bij het voorgezet onderwijs (SLVO) 1982, Sociaal Statistisch Bestand (SSB), Centraal Bureau voor de Statistiek

Mannen die hoogstens basisonderwijs hebben behaald, ontvangen het vaakst een uitkering. Binnen deze groep ontvangt ongeveer één op de acht een uitkering. Dit is aanzienlijk hoger dan bij de andere opleidingsniveaus. Tussen de andere opleidingsniveaus zijn de verschillen wat dit betreft vrij klein. Ook tussen de verschillende opleidingsrichtingen zijn nauwelijks verschillen waarneembaar.

In vergelijking met andere opleidingsniveaus hebben mannen met hoogstens basisonderwijs het vaakst geen inkomensbron. Opvallend is hier bovendien het relatief hoge aandeel mannen zonder inkomstenbron bij нво gezondheidszorg en wo overig (godgeleerdheid, letteren, sociale wetenschappen, wijsbegeerte en pedagogiek). 
In tabel 3.2 wordt de positie in de werkkring van vrouwen weergegeven. Van de vrouwen is ongeveer $70 \%$ werkzaam als werknemer. Ook bij vrouwen neemt de kans om werknemer te zijn toe wanneer het opleidingsniveau stijgt. Van de vrouwen met een HBO- of wo-opleiding is ruim $80 \%$ werknemer en bij het $\mathrm{MBO}$ is dit percentage $76 \%$. Van de laagst opgeleiden varieert het aandeel werknemers van $53 \%$ voor vrouwen met hoogstens basisonderwijs tot $67 \%$ voor vrouwen met als hoogst behaalde opleiding het MAVO. Daarnaast zijn vrouwen van vво overig duidelijk minder vaak werknemer dan vrouwen van de andere richtingen van het vво. Binnen het мво zijn vrouwen van de richting landbouw en overig minder vaak dan gemiddeld werknemer. Vrouwen met een economische opleiding zijn daarentegen vaker dan gemiddeld werknemer. Bovendien blijkt dat binnen het wo degenen met de richting gezondheidszorg het minst vaak werknemer zijn. Deze vrouwen zijn relatief vaak zelfstandige, bijvoorbeeld in een dokterspraktijk, of combineren zelfstandig ondernemerschap met een andere inkomensbron.

\section{Tabel 3-2}

De positie in de werkkring voor vrouwen

\begin{tabular}{|c|c|c|c|c|c|}
\hline Hoogst behaald opleidingsniveau & Zelfstandige & Uitkering & $\begin{array}{c}\text { Geen } \\
\text { inkomstenbron }\end{array}$ & $\begin{array}{l}\text { Gemengde groep } \\
\text { incl. pensioen }\end{array}$ & Werknemer \\
\hline BO & $4 \%$ & $19 \%$ & $16 \%$ & $9 \%$ & $53 \%$ \\
\hline VBO totaal & $4 \%$ & $12 \%$ & $23 \%$ & $6 \%$ & $56 \%$ \\
\hline VBO landbouw & $8 \%$ & $10 \%$ & $25 \%$ & $5 \%$ & $53 \%$ \\
\hline VBO techniek & $8 \%$ & $10 \%$ & $17 \%$ & $11 \%$ & $54 \%$ \\
\hline VBO gezondheidszorg & $3 \%$ & $12 \%$ & $24 \%$ & $5 \%$ & $55 \%$ \\
\hline VBO economie & $6 \%$ & $11 \%$ & $20 \%$ & $6 \%$ & $58 \%$ \\
\hline VBO overig & $0 \%$ & $18 \%$ & $18 \%$ & $36 \%$ & $27 \%$ \\
\hline MAVO & $5 \%$ & $7 \%$ & $14 \%$ & $6 \%$ & $67 \%$ \\
\hline HAVO & $3 \%$ & $4 \%$ & $11 \%$ & $5 \%$ & $77 \%$ \\
\hline MBO totaal & $4 \%$ & $3 \%$ & $13 \%$ & $4 \%$ & $76 \%$ \\
\hline MBO landbouw & $5 \%$ & $0 \%$ & $28 \%$ & $7 \%$ & $60 \%$ \\
\hline MBO techniek & $4 \%$ & $3 \%$ & $9 \%$ & $7 \%$ & $77 \%$ \\
\hline MBO gezondheidszorg & $4 \%$ & $2 \%$ & $13 \%$ & $5 \%$ & $75 \%$ \\
\hline MBO economie & $3 \%$ & $3 \%$ & $10 \%$ & $3 \%$ & $82 \%$ \\
\hline MBO overig & $4 \%$ & $8 \%$ & $19 \%$ & $4 \%$ & $66 \%$ \\
\hline vwo & $4 \%$ & $3 \%$ & $9 \%$ & $8 \%$ & $77 \%$ \\
\hline HBO totaal & $2 \%$ & $2 \%$ & $8 \%$ & $5 \%$ & $83 \%$ \\
\hline HBO landbouw & $0 \%$ & $0 \%$ & $4 \%$ & $12 \%$ & $84 \%$ \\
\hline HBO techniek & $2 \%$ & $2 \%$ & $12 \%$ & $1 \%$ & $83 \%$ \\
\hline HBO gezondheidszorg & $1 \%$ & $1 \%$ & $7 \%$ & $7 \%$ & $84 \%$ \\
\hline HBO economie & $3 \%$ & $5 \%$ & $6 \%$ & $3 \%$ & $83 \%$ \\
\hline $\mathrm{HBO}$ overig & $2 \%$ & $1 \%$ & $10 \%$ & $5 \%$ & $81 \%$ \\
\hline W0 totaal & $3 \%$ & $2 \%$ & $6 \%$ & $7 \%$ & $82 \%$ \\
\hline WO landbouw & $0 \%$ & $6 \%$ & $0 \%$ & $17 \%$ & $78 \%$ \\
\hline WO techniek & $2 \%$ & $2 \%$ & $7 \%$ & $10 \%$ & $80 \%$ \\
\hline W0 gezondheidszorg & $7 \%$ & $2 \%$ & $2 \%$ & $15 \%$ & $74 \%$ \\
\hline WO economie & $1 \%$ & $2 \%$ & $7 \%$ & $7 \%$ & $84 \%$ \\
\hline WO overig & $4 \%$ & $1 \%$ & $8 \%$ & $3 \%$ & $85 \%$ \\
\hline
\end{tabular}

Bron: Schoolloopbaan en herkomst van leerlingen bij het voorgezet onderwijs (SLVO) 1982, Sociaal Statistisch Bestand (SSB), Centraal Bureau voor de Statistiek 
Zelfstandig ondernemerschap onder vrouwen komt relatief weinig voor, ongeveer $3 \%$ van alle vrouwen is zelfstandige. De verschillen tussen de opleidingsniveaus zijn erg klein. Hetzelfde geldt voor de opleidingsrichtingen. Er is echter één uitzondering. Zoals eerder aangeven zijn binnen het wo vooral vrouwen die een opleiding in de gezondheidszorg hebben gevolgd, werkzaam als zelfstandige. Opvallend is dat de groep die meerdere inkomensbronnen combineert onder vrouwen relatief hoog is. Dit zal ten dele veroorzaakt worden doordat vrouwen bij zwangerschap een uitkering in het kader van de ziektewet combineren met een andere inkomensbron.

De kans op een uitkering is het hoogst voor lager opgeleide vrouwen. Van degenen met uitsluitend basisonderwijs ontvangt bijna eenvijfde een uitkering. Van degenen met een VBO-opleiding is dit iets meer dan één op de tien, en bij het MAVO 7\%. Bij de overige opleidingsniveaus is het aandeel vrouwen met een uitkering lager. Van degenen met een HAVO-opleiding of hoger heeft minder dan $5 \%$ een uitkering.

Vrouwen hebben relatief vaak geen inkomstenbron, bijvoorbeeld omdat ze de zorgtaken op zich nemen. Opvallend is dat bijna een kwart van de vrouwen met een vBO-diploma geen inkomstenbron heeft. Dit is verreweg het hoogste van alle opleidingsniveaus. Onder vrouwen met uitsluitend basisonderwijs of MAVO is dit ongeveer 15\%. Hoger opgeleide vrouwen nemen vaker deel aan het arbeidsproces. Naarmate het opleidingsniveau stijgt, neemt de kans om geen inkomstenbron te hebben gestaag af. Bij het vво еn мво zijn het met name de vrouwen met een landbouwgerichte opleiding die geen inkomstenbron hebben. Waarschijnlijk komt dit omdat ze een partner hebben met een landbouwbedrijf. Binnen het нво hebben degenen met een opleiding in de sector techniek relatief vaak geen inkomstenbron.

De positie in de werkkring van mannen verschilt duidelijk van die van vrouwen. Vrouwen hebben duidelijk vaker geen inkomstenbron dan mannen. Dit komt omdat vooral lager opgeleide vrouwen nog altijd vaker dan mannen de zorgtaken voor kinderen op zich nemen en stoppen met werken omdat ze de werk- en gezinstaken niet goed kunnen combineren. Bovendien blijkt dat vrouwen die uitsluitend basisonderwijs of een MAVO-, VBO-diploma hebben behaald vaker een uitkering hebben dan mannen van vergelijkbaar opleidingsniveau. Daarnaast komen vrouwen vaker dan mannen terecht in de gemengde groep, met uitzondering van het Hво. Dit wordt deels veroorzaakt doordat vrouwen bij zwangerschap een uitkering in het kader van de ziektewet combineren met een andere inkomstenbron. Hierdoor zijn mannen vaker werknemer of zelfstandige dan vrouwen.

\subsection{De inkomenspositie}

Figuur 3.3 vermeldt het gemiddeld inkomen per sv-dag voor mannen. Zoals mag worden verwacht neemt het inkomen toe naarmate personen een hoger opleidingsniveau hebben behaald. Figuur 3.3 laat echter een paar opmerkelijke resultaten zien. 
Figuur 3-3

Gemiddeld inkomen per sv-dag (in euro's) van mannen

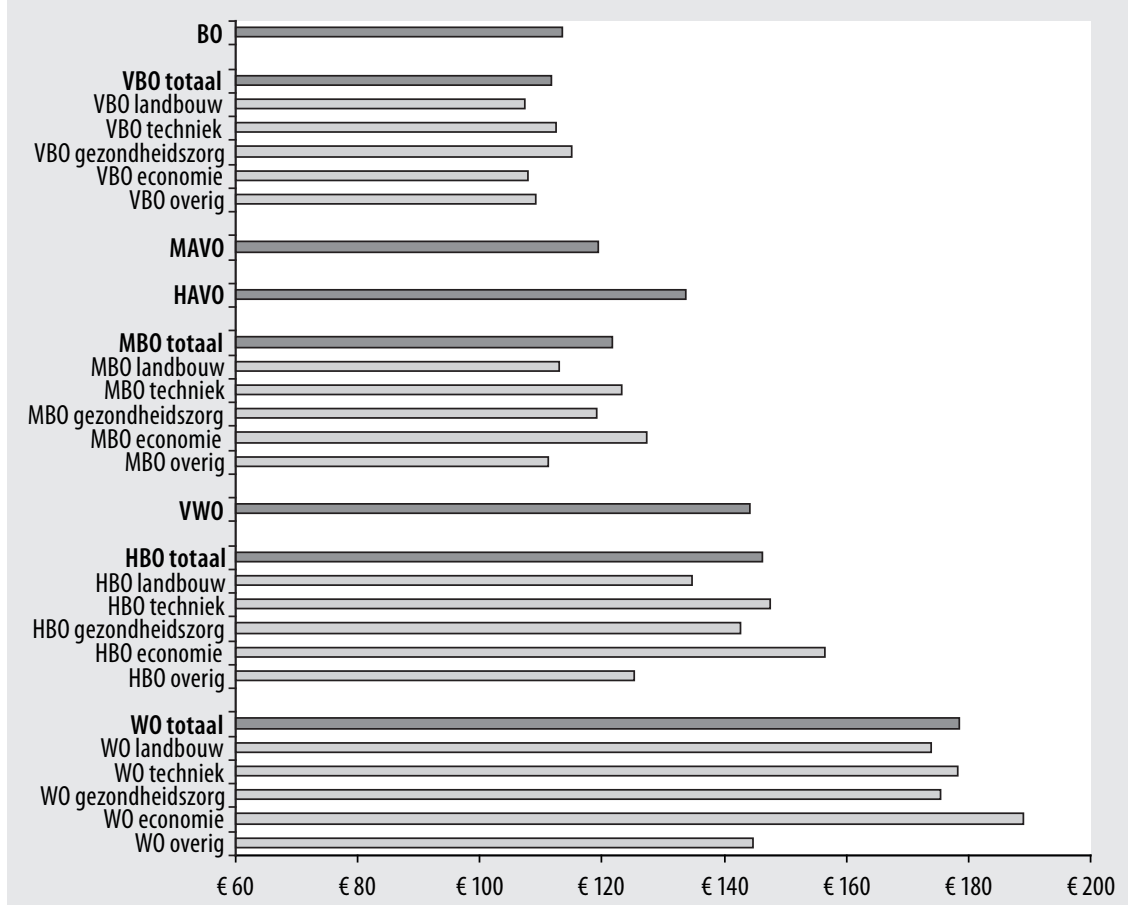

Bron: Schoolloopbaan en herkomst van leerlingen bij het voorgezet onderwijs (SLVO) 1982, Sociaal Statistisch Bestand (SSB), Centraal Bureau voor de Statistiek

Zo verdienen mannen met uitsluitend basisonderwijs en een vво-diploma gemiddeld ongeveer even veel ( $€$ II2,- per sv-dag). Degenen die geen opleiding hebben afgemaakt en degenen met een vво-diploma hebben op de langere termijn dus ongeveer een vergelijkbaar inkomen. Waarschijnlijk speelt hierbij mee dat Nederland het minimumloon kent. En waarschijnlijk is het merendeel van de mannen zonder diploma of een vво-diploma in banen met de laagste inkomens terechtgekomen.

Daarnaast is opmerkelijk dat het gemiddeld inkomen van mannen met een MAVOdiploma vrijwel even hoog is als die van mannen met een мво-diploma. Hier geldt dat binnen het мво vooral degenen met een opleiding in de richting landbouw of overig duidelijk minder verdienen dan degenen met een opleiding in de richting techniek of economie. Bovendien komt naar voren dat degenen met een HAVO- of vwodiploma duidelijk meer verdienen dan degenen met een мво-diploma. Het blijkt zelfs dat het gemiddeld inkomen per sv-dag van mannen met een vwo-diploma vrijwel gelijk is aan die van mannen met een нво-diploma (ongeveer €I45,- per sv-dag). Binnen het нво is het inkomen van mannen met een economische opleiding duidelijk het hoogst. Binnen het нво verdienen degenen met een opleiding in de richting landbouw of overig relatief weinig. Verder is opvallend dat bij de overgang van нво 
naar wo het inkomen een flinke sprong maakt. Voor mannen met een wo-diploma is het gemiddeld inkomen $€ \mathrm{I} 78$,- per sv-dag. Binnen het wo verdienen degenen van een economische opleiding het meest. Verder blijkt ook hier dat degenen van de richting overig relatief weinig verdienen. Dat mannen met een opleiding in de richting gezondheidszorg hier minder verdienen dan mannen met een economische achtergrond heeft waarschijnlijk te maken met het gegeven dat het merendeel van de medici nog in een opleidingstraject zitten.

Figuur 3.4 laat het gemiddeld inkomen per sv-dag voor vrouwen zien. Opvallend is hier dat voor lager opgeleide vrouwen een diploma niet doorslaggevend is voor de inkomenspositie op de langere termijn. Vrouwen met een vвO-diploma hebben het laagste gemiddeld inkomen per sv-dag. Dit is bij alle richtingen binnen het vво lager dan voor vrouwen met uitsluitend basisonderwijs. Bovendien komt naar voren dat het gemiddeld inkomen per sv-dag van vrouwen met uitsluitend basisonderwijs vrij weinig verschilt van die van vrouwen met een MAVO- of MBO-diploma (ongeveer $€$ 90,-). Overigens bestaan er binnen het мво wat dit betreft duidelijke verschillen naar richting. De inkomenspositie voor vrouwen van de richtingen techniek en economie is duidelijk beter dan voor vrouwen van andere richtingen in het мво.

\section{Figuur 3-4}

Gemiddeld inkomen per sv-dag (in euro's) van vrouwen

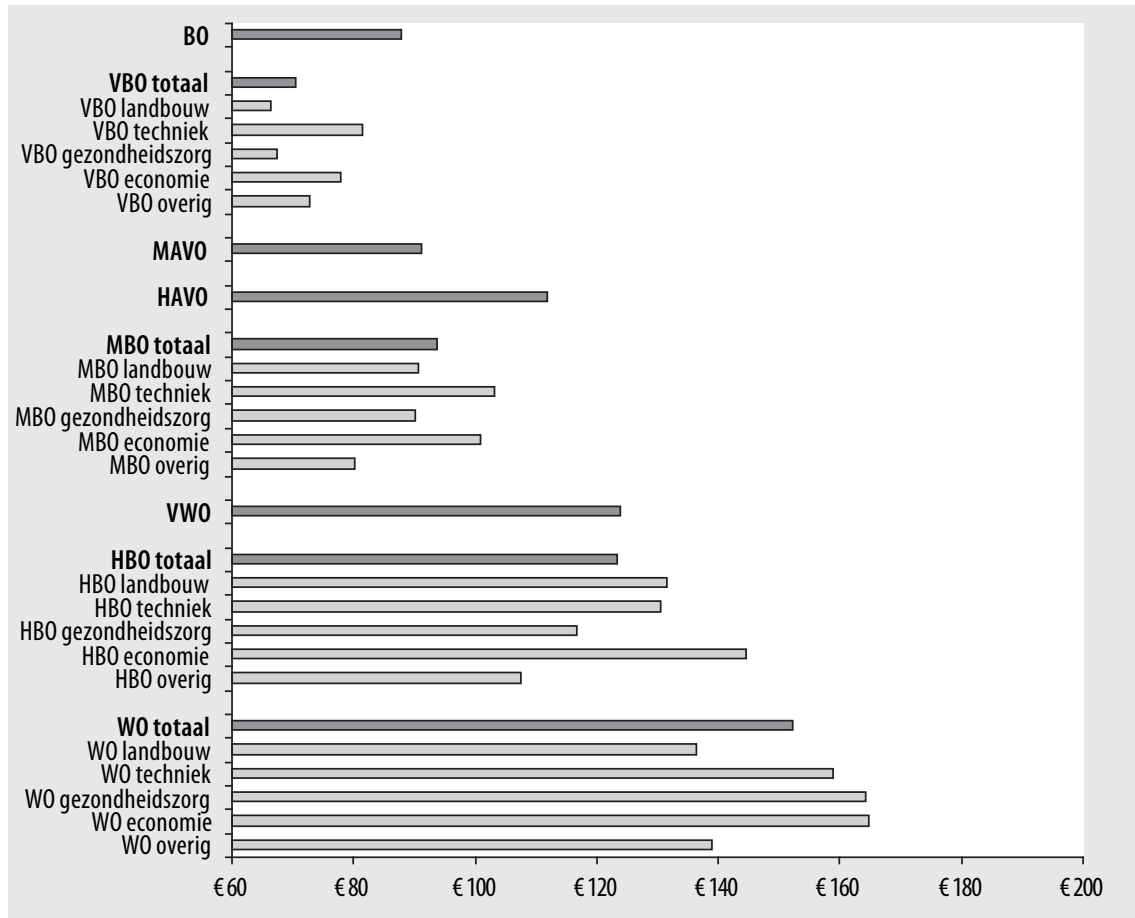

Bron: Schoolloopbaan en herkomst van leerlingen bij het voorgezet onderwijs (SLVO) 1982, Sociaal Statistisch Bestand (SSB), Centraal Bureau voor de Statistiek 
Voor vrouwen die het HAvO of het vwo hebben behaald is het gemiddeld inkomen per sv-dag wel duidelijk hoger dan die van vrouwen met uitsluitend basisonderwijs. Net als bij mannen blijkt dat vrouwen met een vwo-diploma ongeveer even veel verdienen als vrouwen met een нво-diploma. Binnen het нво verdienen vrouwen met een economische opleiding relatief veel, terwijl vrouwen met een opleiding in de gezondheidszorg en de richting overig juist relatief weinig verdienen. Verder blijkt ook hier dat vrouwen met een wo-diploma duidelijk meer verdienen dan vrouwen met een нво-diploma. Binnen het wo verdienen vrouwen met de richting gezondheidszorg daarentegen relatief veel, evenals degenen met een economische opleiding.

Wanneer de inkomenspositie van mannen wordt vergeleken met die van vrouwen dan blijkt dat vrouwen doorgaans een lager gemiddeld inkomen per sv-dag hebben dan mannen. Op zich is dit niet opmerkelijk, aangezien eerdere studies naar de inkomenspositie van mannen en vrouwen dit ook hebben laten zien. Opvallend is wel dat het verschil in beloning tussen mannen en vrouwen met een vво-diploma. Dit verschil is gemiddeld maar liefst $€ 40$,- per sv-dag. Ter vergelijking; bij degenen met uitsluitend basisonderwijs is het verschil in inkomen per sv-dag tussen mannen en vrouwen $€ 25$,-, bij het мво $€ 28$,-, en bij het wo is dit verschil $€ 26,-$. 



\section{Welke factoren bepalen de arbeidsmarktpositie van dertigers?}

\subsection{Inleiding}

Onderwijs speelt een belangrijke rol bij de allocatie op de arbeidsmarkt. Daarom is het van belang beter inzicht te krijgen in de achterliggende factoren die verklaren waarom de gevolgde opleiding zo'n belangrijke voorspeller is voor het latere arbeidsmarktsucces. Bij de intrede op de arbeidsmarkt gaat het vooral om de vraag of de opleiding mensen voldoende startbekwaam heeft gemaakt. Dit uit zich vooral in een effect van specifieke kennis en vaardigheden. Voor de lange termijn zijn echter meer generieke competenties van belang om de 'employability' van afgestudeerden te verzekeren.

In dit hoofdstuk staat de vraag centraal in hoeverre het effect van opleiding op de arbeidsmarktpositie van dertigers kan worden toegeschreven aan het bereikte opleidingsniveau, sociale herkomst, cognitieve vaardigheden en onderwijsondersteunend thuisklimaat. Door middel van multivariate regressie-analyse wordt de afzonderlijke invloed van deze kenmerken onderzocht. Het voordeel van een dergelijke analyse is dat de zelfstandige invloed van meerdere kenmerken tegelijkertijd in één analyse kunnen worden bepaald. Zoals eerder gezegd zijn sociale herkomst, cognitieve vaardigheden en de thuissituatie van de oud-leerlingen van het sLvo gemeten op I2-jarige leeftijd.

Eerst is het hoogst behaalde opleidingsniveau geanalyseerd. Het is belangrijk dit eerst te laten zien omdat op deze manier kan worden aangeven in hoeverre sociale herkomst, cognitieve vaardigheden en onderwijsondersteunend thuisklimaat indirect de arbeidsmarktpositie op de lange termijn bepalen (zie figuur I.I). Verwacht mag worden dat de genoemde kenmerken van invloed zijn op het hoogst behaalde opleidingsniveau en personen met een hoog opleidingsniveau hebben een betere positie op de arbeidsmarkt dan laagopgeleiden.

Vervolgens wordt aan de hand van een logistische regressie analyse de kans op minstens één baan bepaald. Daarna is een multinomiale logitanalyse uitgevoerd van de positie in de werkkring (werknemer, zelfstandige, uitkering, geen inkomstenbron of gemengde groep). Tot slot is een lineaire regressie analyse uitgevoerd van de beloning. Deze laatste drie analyses zijn apart voor mannen en vrouwen uitgevoerd. 


\subsection{Bereikt opleidingsniveau}

Tabel I gaat in op de resultaten van de analyse van het hoogst behaalde opleidingsniveau. Er zijn drie modellen geschat. In het eerste model zijn sekse, etniciteit, opleidingsniveau ouders en maatschappelijke positie ouders opgenomen. Het intercept laat hier het gemiddeld bereikte opleidingsniveau (in jaren) zien van een mannelijke allochtoon, waarvan de ouders niet werkzaam zijn en waarvan de ouders alléén basisonderwijs hebben. Dit intercept bedraagt 9,I5 jaren opleiding, wat ongeveer vergelijkbaar is met het derde jaar in het vвo.

\section{Tabel 4-1}

Resultaten van de analyse van het hoogst bereikte opleidingsniveau ( $N=14,491)$ : ongestandaardiseerde regressiecoëfficiënten (gestandaardiseerde effecten tussen haakjes)

\begin{tabular}{|c|c|c|c|c|c|c|}
\hline & \multicolumn{2}{|c|}{ Model 1} & \multicolumn{2}{|c|}{ Model 2} & \multicolumn{2}{|c|}{ Model 3} \\
\hline Intercept & $9,15^{* *}$ & & $7,49^{* *}$ & & $3,15^{* *}$ & \\
\hline \multicolumn{7}{|l|}{ Sekse } \\
\hline Man (ref.) & - & & - & & - & \\
\hline Vrouw & 0,08 & $(0,01)$ & $0,13^{*}$ & $(0,02)$ & 0,01 & $(0,00)$ \\
\hline \multicolumn{7}{|l|}{ Etniciteit } \\
\hline Autochtoon (ref.) & - & & - & & - & \\
\hline Allochtoon & $-0,94^{* *}$ & $(-0,07)$ & $-0,65^{* *}$ & $(-0,05)$ & $-0,78^{* *}$ & $(-0,06)$ \\
\hline Opleidingsniveau ouders & $0,25^{* *}$ & $(0,23)$ & $0,14^{* *}$ & $(0,13)$ & $0,11^{* *}$ & $(0,10)$ \\
\hline \multicolumn{7}{|l|}{ Maatschappelijke positie ouders } \\
\hline Niet werkzaam (ref.) & - & & - & & - & \\
\hline Arbeider & $0,86^{* *}$ & $(0,12)$ & $0,74^{* *}$ & $(0,10)$ & $0,74^{* *}$ & $(0,10)$ \\
\hline Zelfstandige zonder personeel & $1,54^{* *}$ & $(0,11)$ & $1,25^{* *}$ & $(0,09)$ & $1,23^{* *}$ & $(0,09)$ \\
\hline Zelfstandige met personeel & $1,16^{* *}$ & $(0,07)$ & $0,78^{* *}$ & $(0,05)$ & $0,71^{* *}$ & $(0,04)$ \\
\hline Lagere employee & $1,49^{* *}$ & $(0,14)$ & $1,05^{* *}$ & $(0,10)$ & $0,92^{* *}$ & $(0,09)$ \\
\hline Middelbare employee & $1,57^{* *}$ & $(0,17)$ & $1,05^{* *}$ & $(0,12)$ & $0,85^{* *}$ & $(0,09)$ \\
\hline Hogere employee & $1,57^{* *}$ & $(0,15)$ & $0,94^{* *}$ & $(0,09)$ & $0,69^{* *}$ & $(0,06)$ \\
\hline Leesgedrag leerling & & & $0,11^{* *}$ & $(0,03)$ & 0,04 & $(0,01)$ \\
\hline Onderwijsondersteunend thuisklimaat & & & $-0,11$ & $(-0,01)$ & $-0,03$ & $(-0,00)$ \\
\hline Schoolprestaties & & & $4,51^{* *}$ & $(0,37)$ & $2,74^{* *}$ & $(0,23)$ \\
\hline Non-verbale intelligentie & & & $0,75^{* *}$ & $(0,05)$ & $0,50^{* *}$ & $(0,03)$ \\
\hline Schooladvies & & & & & $0,83^{* *}$ & $(0,25)$ \\
\hline $\mathrm{R}^{2}$ & & & & & & \\
\hline
\end{tabular}

${ }^{*}=p<0,05 ;{ }^{* *}=p<0,01 ;$ ref. $=$ referentiecategorie

Bron: Schoolloopbaan en herkomst van leerlingen bij het voorgezet onderwijs (SLVO) 1982; Sociaal Statistisch Bestand (SSB), Centraal Bureau voor de Statistiek

Uit model I blijkt dat er duidelijk sprake is van een invloed van sociale herkomst op het bereikte opleidingsniveau. Ten eerste heeft het opleidingsniveau van de ouders een sterk effect op de loopbaan van de kinderen. Wanneer het opleidingsniveau van de ouders met I jaar toe neemt, neemt het bereikte opleidingsniveau van hun kinderen gemiddeld met 0,25 jaar toe. Ten tweede bepaalt de maatschappelijke positie van de kostwinner mede het bereikte opleidingsniveau van de kinderen. Daarbij hebben kinderen van kostwinners die niet werkzaam zijn het laagste opleidingsniveau behaald. 
Kinderen van arbeiders en van zelfstandigen met personeel behalen een niveau dat gemiddeld ongeveer één jaar hoger ligt. De kinderen van de overige groepen behalen een opleidingsniveau dat gemiddeld anderhalf jaar hoger ligt. Daarnaast blijkt dat er geen significante verschillen bestaan tussen mannen en vrouwen. Allochtonen bereiken een opleidingsniveau dat gemiddeld één jaar lager ligt dan dat van autochtonen.

In model 2 zijn leesgedrag, onderwijsondersteunend thuisklimaat, schoolprestaties en non-verbale intelligentie toegevoegd aan het eerste model. Op deze manier kan worden bepaald in hoeverre de invloed van sociale herkomst op het bereikte opleidingsniveau in model I overeind blijft wanneer rekening wordt gehouden met cognitieve kenmerken van leerlingen.

De verklaarde variantie tussen model I en model 2 is toegenomen van I $2 \%$ naar $26 \%$. Dit betekent dat de toegevoegde kenmerken voor een belangrijk deel het te bereiken onderwijsniveau bepalen. Schoolprestaties leveren de grootste bijdrage aan het te bereiken onderwijsniveau (de gestandaardiseerde bèta bedraagt 0,37 , terwijl de bèta voor non-verbale intelligentie slechts 0,05 bedraagt). Het effect van sociale herkomst op het bereikte opleidingsniveau neemt af wanneer wordt gecontroleerd voor schoolprestaties en intelligentie. Het zelfstandige effect van het opleidingsniveau van de ouders wordt bijna gehalveerd en bedraagt nu O,I4 in plaats van 0,25 . Ook het effect van de maatschappelijke positie neemt met zo'n I5 tot 40\% af. Met andere woorden; leerlingen van hogere sociale herkomst bereiken een hoger opleidingsniveau omdat de onderwijsprestaties op I2-jarige leeftijd beter zijn dan van leerlingen van lagere sociale herkomst.

Bij etnische herkomst loopt het effect met 31\% terug van 0,94 naar 0,65. Verder heeft het onderwijsondersteunend thuisklimaat geen significante invloed op het bereikte opleidingsniveau. Ondanks het feit dat gecontroleerd wordt voor intelligentie en schoolprestaties is ook het leesgedrag van invloed op het bereikte opleidingsniveau. Naarmate een leerling per week meer boeken heeft gelezen, neemt het bereikte opleidingsniveau toe. In het laatste model is het schooladvies toegevoegd. De reden hiervoor is dat het schooladvies bepaald wordt door verschillende kenmerken zoals schoolprestaties, sociaal milieu en motivatie. Door schooladvies als laatste op te nemen in het model en te kijken naar de afname van de effecten van eerder in het model opgenomen variabelen wordt inzichtelijk gemaakt waar het advies van de leraar op is gebaseerd. Het schooladvies levert inderdaad een sterke positieve bijdrage aan het uiteindelijk behaalde opleidingsniveau. Tegelijkertijd neemt het effect van schoolprestaties met ongeveer $40 \%$ af, verdwijnt ongeveer eenderde van het effect van intelligentie en neemt (in mindere mate) ook het effect van sociale herkomst af. Bovendien wordt het effect van leesgedrag van de leerling meer dan gehalveerd en is niet meer significant. Hieruit kan worden afgeleid dat het schooladvies vooral is gebaseerd op schoolprestaties en cognitieve kenmerken en in mindere mate ook op sociale herkomst. 


\subsection{De arbeidsmarktpositie van dertigers}

Uit de analyse van de kans op het hebben van een baan blijkt dat het behalen van een hoog opleidingsniveau loont voor oud-leerlingen van het sLvo-cohort. Voor zowel mannen als vrouwen stijgt de kans op het hebben van werk naarmate het opleidingsniveau toeneemt. Omgerekend in termen van odds ratio's is de kansverhouding van werk tegenover geen werk voor mannen met een wo diploma ongeveer zes keer groter dan de overeenkomstige kansverhouding voor mannen met uitsluitend basisonderwijs $\left(\mathrm{e}^{\left({ }^{13}{ }^{*} \mathrm{O}, \mathrm{I} 4\right)}=6,2\right)$. Overigens is bij vrouwen de invloed van het bereikte opleidingsniveau op de kans op werk groter dan bij mannen $\left(e^{\left(13^{*} 0,22\right)}=17,5\right)$.

Tabel 4-2

Resultaten van de analyse van de kans op het hebben van een baan van mannen: logit-effecten (gestandaardiseerde effecten tussen haakjes)

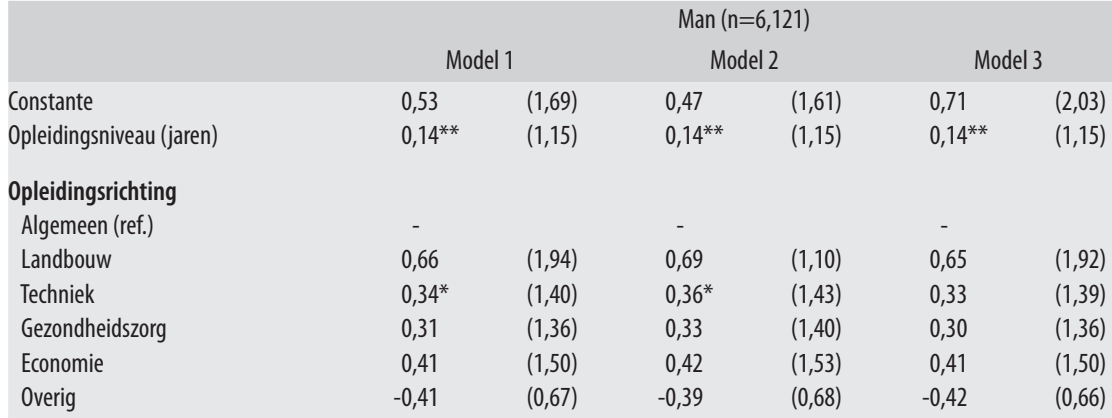

\section{Etniciteit}

Autochtoon (ref.)

Allochtoon

$\begin{array}{cccccc}-0,73^{* *} & (0,48) & -0,72^{* *} & (0,49) & -0,71^{* *} & (0,49) \\ 0,03 & (1,03) & 0,02 & (1,02) & 0,02 & (1,02)\end{array}$

Opleidingsniveau ouders

Maatschappelijke positie ouders

Niet werkzaam (ref.)

Arbeider

$0,83^{* *} \quad(2,30) \quad 0,83^{* *} \quad(2,29) \quad 0,83^{* *} \quad(2,30$

Zelfstandige zonder personeel

$1,01^{* *} \quad(2,74)$

$1,01^{* *}$

$(2,75)$

$1,01^{* *}$

Zelfstandige met personeel

$0,54 \quad(1,71)$

0,53

Lagere employee

$0,71^{* *} \quad(2,03)$

$0,69^{* *}$

$(1,69)$

0,53

Middelbare employee

$0,47^{*} \quad(1,60)$

$0,46^{*}$

$(2,00)$

$0,70^{* *}$

$(1,69)$

Hogere employee

0,43

$(1,54)$

0,42

$(1,58)$

$0,47^{*}$

Leesgedrag leerling

Onderwijsondersteunend thuisklimaat

$-0,06$

$(1,53)$

0,43

$(1,60)$

Schoolprestaties

Schooladvies

$(1,21)$

${ }^{*}=\mathrm{p}<0,05 ;{ }^{* *}=\mathrm{p}<0,01 ; \mathrm{x}=$ te weinig waarnemingen; ref. = referentiecategorie

Bron: Schoolloopbaan en herkomst van leerlingen bij het voorgezet onderwijs (SLVO) 1982; Sociaal Statistisch Bestand (SSB), Centraal Bureau voor de Statistiek 
Tabel 4-3

Resultaten van de analyse van de kans op het hebben van een baan van vrouwen: logit-effecten (gestandaardiseerde effecten tussen haakjes)

\begin{tabular}{|c|c|c|c|c|c|c|}
\hline \multirow[b]{3}{*}{ Constante } & \multicolumn{6}{|c|}{ Vrouw $(n=5,621)$} \\
\hline & \multicolumn{2}{|c|}{ Model 1} & \multicolumn{2}{|c|}{ Model 2} & \multicolumn{2}{|c|}{ Model 3} \\
\hline & $-0,74^{* *}$ & $(0,48)$ & $-0,70^{*}$ & $(0,50)$ & $-1,47^{* *}$ & $(0,23)$ \\
\hline Opleidingsniveau (jaren) & $0,22^{* *}$ & $(1,25)$ & $0,20^{* *}$ & $(1,23)$ & $0,19^{* *}$ & $(1,21)$ \\
\hline \multicolumn{7}{|l|}{ Opleidingsrichting } \\
\hline Algemeen (ref.) & - & & - & & - & \\
\hline Landbouw & $-0,17$ & $(0,84)$ & $-0,08$ & $(0,93)$ & $-0,02$ & $(1,02)$ \\
\hline Techniek & $-0,47^{*}$ & $(0,62)$ & $-0,36$ & $(0,70)$ & $-0,29 *$ & $(0,75)$ \\
\hline Gezondheidszorg & $-0,19$ & $(0,83)$ & $-0,08$ & $(0,92)$ & 0,01 & $(1,01)$ \\
\hline Economie & $-0,14$ & $(0,87)$ & $-0,08$ & $(0,93)$ & $-0,02$ & $(0,98)$ \\
\hline Overig & $-0,10$ & $(0,91)$ & $-0,02$ & $(0,98)$ & $-0,05$ & $(1,05)$ \\
\hline \multicolumn{7}{|l|}{ Etniciteit } \\
\hline Autochtoon (ref.) & - & & - & & - & \\
\hline Allochtoon & $-0,45^{* *}$ & $(0,64)$ & $-0,42^{* *}$ & $(0,66)$ & $-0,44^{* *}$ & $(0,64)$ \\
\hline Opleidingsniveau ouders & $0,05^{* *}$ & $(1,05)$ & $0,04^{*}$ & $(1,05)$ & 0,04 & $(1,04)$ \\
\hline \multicolumn{7}{|l|}{ Maatschappelijke positie ouders } \\
\hline Niet werkzaam (ref.) & - & & - & & - & \\
\hline Arbeider & 0,22 & $(1,25)$ & 0,22 & $(1,24)$ & 0,22 & $(1,24)$ \\
\hline Zelfstandige zonder personeel & 0,41 & $(1,50)$ & 0,37 & $(1,45)$ & 0,35 & $(1,43)$ \\
\hline Zelfstandige met personeel & 0,31 & $(1,36)$ & 0,27 & $(1,31)$ & 0,26 & $(1,29)$ \\
\hline Lagere employee & 0,18 & $(1,20)$ & 0,15 & $(1,16)$ & 0,13 & $(1,14)$ \\
\hline Middelbare employee & $0,39^{*}$ & $(1,48)$ & 0,36 & $(1,43)$ & 0,33 & $(1,40)$ \\
\hline Hogere employee & 0,36 & $(1,44)$ & 0,31 & $(1,36)$ & 0,28 & $(1,32)$ \\
\hline Leesgedrag leerling & & & $-0,07$ & $(0,93)$ & $-0,08$ & $(0,92)$ \\
\hline Onderwijsondersteunend thuisklimaat & & & 0,24 & $(1,27)$ & 0,25 & $(1,29)$ \\
\hline Schoolprestaties & & & $0,61^{* *}$ & $(1,84)$ & 0,37 & $(1,45)$ \\
\hline Non-verbale intelligentie & & & 0,08 & $(1,08)$ & 0,03 & $(1,03)$ \\
\hline Schooladvies & & & & & 0,15 & $(1,16)$ \\
\hline Nagelkerke $\mathrm{R}^{2}$ & 0,09 & & 0,12 & & 0,12 & \\
\hline
\end{tabular}

${ }^{*}=\mathrm{p}<0,05 ;{ }^{* *}=\mathrm{p}<0,01 ; \mathrm{x}=$ te weinig waarnemingen; ref. $=$ referentiecategorie

Bron: Schoolloopbaan en herkomst van leerlingen bij het voorgezet onderwijs (SLVO) 1982; Sociaal Statistisch Bestand (SSB), Centraal Bureau voor de Statistiek

Daarnaast is ook de etnische herkomst van personen van invloed op de kans op werk. Over het algemeen is de kans op werk kleiner voor allochtonen dan voor autochtonen. Verder is vooral voor mannen de maatschappelijke positie van de ouders van invloed op de kans op een baan. Daarbij geldt dat mannen waarvan de ouders niet werkzaam zijn de grootste kans hebben om zelf niet werkzaam te zijn. Deze invloed blijft geheel overeind wanneer in model 2 en model 3 rekening wordt gehouden met leesgedrag, onderwijsondersteunend thuisklimaat, schoolprestaties, non-verbale intelligentie en schooladvies. Met andere woorden; ook bij gelijke onderwijsprestaties hebben mannen waarvan de ouders niet werkzaam zijn nog altijd een kleinere kans op werk dan mannen waarvan de ouders wel werk hebben. Voor vrouwen is vooral het opleidingsniveau van de ouders en in mindere mate de maatschappelijke positie van de ouders van invloed op de kans op werk. 
Vervolgens is onderzocht welke factoren een rol spelen bij de positie in de werkkring. Dit is gedaan aan de hand van een multinominale logitanalyse. Hierin wordt de kans op een bepaalde positie geschat (zelfstandige, uitkering, geen inkomstenbron, gemengde groep) relatief ten opzichte van de kans om werknemer te zijn. Dit is eerst gedaan voor mannen. Hieruit komt naar voren dat het behaalde opleidingsniveau van invloed is op de positie die mannen innemen in de werkkring. Het blijkt dat mannen met een laag opleidingsniveau een significant grotere kans hebben op een uitkering dan mannen die een hoger opleidingsniveau hebben bereikt. Omgerekend in termen van odds ratio's is de kansverhouding van een uitkering tegenover werknemer voor mannen met uitsluitend basisonderwijs acht keer groter dan de overeenkomstige kansverhouding voor mannen met een wo-diploma $\left(\mathrm{e}^{(13 * 0,16)}=8,0\right)$.

\section{Tabel 4-4}

Resultaten van de multinomiale logitanalyse van de positie in de werkkring van mannen ( $N=6.363)$ : logit-effecten (gestandaardiseerde effecten tussen haakjes)

\begin{tabular}{|c|c|c|c|c|c|c|c|c|}
\hline \multirow[b]{2}{*}{ Constante } & \multicolumn{2}{|c|}{$\begin{array}{l}\text { Zelfstandige }^{1} \\
\quad(\mathrm{n}=477)\end{array}$} & \multicolumn{2}{|c|}{$\begin{array}{l}\text { Uitkering }^{1} \\
(\mathrm{n}=247)\end{array}$} & \multicolumn{2}{|c|}{$\begin{array}{l}\text { Geen inkomstenbron }{ }^{1} \\
\qquad(n=242)\end{array}$} & \multicolumn{2}{|c|}{$\begin{array}{l}\text { Gemengde groep }{ }^{1} \\
\qquad(n=333)\end{array}$} \\
\hline & $-0,63$ & & $-0,55$ & & $-3,99 * *$ & & $-1,65^{* *}$ & \\
\hline Opleidingsniveau (jaren) & $-0,11^{* *}$ & $(0,89)$ & $-0,16^{* *}$ & $(0,85)$ & $-0,03$ & $(0,97)$ & $-0,03$ & $(0,97)$ \\
\hline \multicolumn{9}{|l|}{ Opleidingsrichting } \\
\hline Algemeen (ref.) & - & & - & & - & & - & \\
\hline Landbouw & $1,32^{* *}$ & $(3,72)$ & $-0,85$ & $(0,43)$ & $-0,70$ & $(0,50)$ & $0,86^{* *}$ & $(2,35)$ \\
\hline Techniek & 0,07 & $(1,07)$ & $-0,35$ & $(0,70)$ & $-0,35$ & $(0,71)$ & 0,02 & $(1,02)$ \\
\hline Gezondheidszorg & 0,51 & $(1,67)$ & $-0,82$ & $(0,44)$ & $-0,08$ & $(0,93)$ & $-0,18$ & $(0,83)$ \\
\hline Economie & 0,10 & $(1,10)$ & $-0,33$ & $(0,72)$ & $-0,42$ & $(0,66)$ & $-0,11$ & $(0,90)$ \\
\hline Overig & $0,60^{*}$ & $(1,81)$ & 0,54 & $(1,71)$ & $-0,10$ & $(0,91)$ & 0,22 & $(1,25)$ \\
\hline \multicolumn{9}{|l|}{ Etniciteit } \\
\hline Autochtoon (ref.) & - & & - & & - & & - & \\
\hline Allochtoon & $-0,13$ & $(0,88)$ & $0,76^{* *}$ & $(2,13)$ & $0,70^{* *}$ & $(2,02)$ & 0,36 & $(1,44)$ \\
\hline Opleidingsniveau ouders & $-0,03$ & $(0,97)$ & $-0,03$ & $(0,97)$ & 0,00 & $(1,00)$ & 0,02 & $(1,02)$ \\
\hline \multicolumn{9}{|l|}{ Maatschappelijke positie ouders } \\
\hline Niet werkzaam (ref.) & - & & - & & - & & - & \\
\hline Arbeider & $-0,42^{*}$ & $(0,66)$ & $-0,79^{* *}$ & $(0,45)$ & $-0,70^{* *}$ & $(0,50)$ & $-0,43^{*}$ & $(0,65)$ \\
\hline Zelfstandige zonder personeel & $1,43^{* *}$ & $(4,17)$ & $-0,68$ & $(0,50)$ & $-0,15$ & $(0,86)$ & 0,44 & $(1,55)$ \\
\hline Zelfstandige met personeel & $1,20^{* *}$ & $(3,32)$ & $-0,14$ & $(0,87)$ & $-0,05$ & $(0,78)$ & $-0,11$ & $(0,89)$ \\
\hline Lagere employee & $-0,25$ & $(0,78)$ & $-0,64^{*}$ & $(0,53)$ & $-0,65^{*}$ & $(0,52)$ & $-0,37$ & $(0,69)$ \\
\hline Middelbare employee & 0,26 & $(1,30)$ & $-0,36$ & $(0,70)$ & $-0,32$ & $(0,73)$ & $-0,30$ & $(0,74)$ \\
\hline Hogere employee & 0,44 & $(1,56)$ & $-0,34$ & $(0,71)$ & $-0,22$ & $(0,80)$ & $-0,48$ & $(0,62)$ \\
\hline Leesgedrag leerling & $-0,15^{* *}$ & $(0,86)$ & 0,10 & $(1,11)$ & $0,16^{*}$ & $(1,18)$ & $-0,06$ & $(0,94)$ \\
\hline Onderwijsondersteunend thuisklimaat & 0,09 & $(1,09)$ & $-0,24$ & $(0,79)$ & $-0,04$ & $(0,96)$ & $-0,30$ & $(0,74)$ \\
\hline Schoolprestaties & 0,43 & $(1,54)$ & $-0,05$ & $(0,95)$ & $-0,08$ & $(0,92)$ & 0,52 & $(1,67)$ \\
\hline Non-verbale intelligentie & $-0,40$ & $(0,67)$ & $-0,33$ & $(0,72)$ & $-0,42$ & $(0,66)$ & $-0,06$ & $(0,94)$ \\
\hline Schooladvies & $-0,03$ & $(0,98)$ & 0,03 & $(1,03)$ & $0,23^{*}$ & $(1,25)$ & $-0,09$ & $(0,91)$ \\
\hline Nagelkerke $\mathrm{R}^{2}$ & & & & & 12 & & & \\
\hline
\end{tabular}

${ }^{1}$ relatief ten opzichte van werknemer $(n=5.064) ;{ }^{*}=p<0,05 ;{ }^{* *}=p<0,01$; ref. $=$ referentiecategorie Bron: Schoolloopbaan en herkomst van leerlingen bij het voorgezet onderwijs (SLVO) 1982; Sociaal Statistisch Bestand (SSB), Centraal Bureau voor de Statistiek 
Daarnaast zijn lager opgeleide mannen vaker werkzaam als zelfstandige dan hoger opgeleide mannen. Bovendien zijn voornamelijk degenen met een landbouwgerichte opleiding werkzaam als zelfstandig ondernemer. Mannen met een landbouwgerichte opleiding behoren relatief vaak tot de gemengde groep, waar meerdere vormen arbeidsposities worden gecombineerd. Door de vaak sterk wisselde inkomsten uit de onderneming combineren ze vaak zelfstandig ondernemerschap met werknemerschap of een uitkering. Etnische herkomst heeft ook een significante invloed op de positie in de werkkring. Daarbij hebben allochtone mannen vaker een uitkering of geen inkomstenbron dan autochtone mannen.

Sociale herkomst heeft voor mannen - naast een indirect effect via het behaalde opleidingsniveau - ook een direct effect op de positie in de werkkring. Zelfstandig ondernemerschap wordt bij mannen doorgegeven van ouder op kind. Mannen waarvan de ouders werkzaam zijn als zelfstandig ondernemer hebben een relatief grote kans om zelf als zelfstandige te werken. Daarnaast hebben mannen die afkomstig zijn uit een arbeidersmilieu of waarvan de ouders werkzaam zijn als lagere employee significant minder vaak een uitkering of geen inkomstenbron dan mannen waarvan de ouders niet werkzaam zijn. Bovendien zijn mannen uit arbeidersmilieus minder vaak zelfstandig ondernemer en behoren minder vaak tot de gemengde groep dan mannen met niet werkzame ouders.

Opvallend is dat schoolprestaties, non-verbale intelligentie en schooladvies bij mannen in de meeste gevallen geen significante effecten laten zien op de positie in de werkkring. Dit betekent dat er voor mannen geen directe invloed is van deze kenmerken op de latere positie in de werkkring, maar uitsluitend via het behaalde opleidingsniveau. Er is één uitzondering: het schooladvies heeft een positief effect op de kans om geen inkomstenbron te hebben. Daarnaast heeft het leesgedrag van de leerling invloed op de latere arbeidsmarktpositie. Mannen die veel boeken hebben gelezen in het laatste jaar van het basisonderwijs, zijn op latere leeftijd minder vaak zelfstandige en hebben vaker geen inkomstenbron dan mannen die weinig boeken hebben gelezen.

Ook vrouwen die een laag opleidingsniveau hebben behaald, hebben vaker een uitkering dan degenen die een hoog opleidingsniveau hebben behaald. Dit effect is voor vrouwen nog iets sterker dan voor mannen. Omgerekend in termen van odds ratio's is de kansverhouding van een uitkering tegenover werknemer voor de laagst opgeleide vrouwen ongeveer drieëntwintig keer groter dan de overeenkomstige kansverhouding voor de hoogst opgeleide vrouwen $\left(\mathrm{e}^{\left({ }^{1} 3^{*}, 24\right)}=22,6\right)$. Bovendien zijn lager opgeleide vrouwen, net als mannen, vaker werkzaam als zelfstandige dan hoger opgeleide vrouwen. Een belangrijk verschil tussen mannen en vrouwen is echter dat bij vrouwen het bereikte opleidingsniveau van invloed is op de kans om later geen inkomstenbron te hebben. Het blijkt dat lager opgeleide vrouwen significant vaker geen inkomstenbron hebben dan hoger opgeleide vrouwen. Verder is de positie in de werkkring van allochtone vrouwen minder gunstig dan die van autochtone vrouwen, ze hebben vaker een uitkering. 
Het sociaal milieu heeft voor vrouwen vrij weinig invloed op de positie in de werkkring. Vrouwen zijn relatief vaak werkzaam als zelfstandig ondernemer wanneer de ouders ook werkzaam zijn als zelfstandige met personeel. Voor vrouwen waarvan de ouders lagere employee zijn geldt juist het tegenovergestelde. Verder behoren vrouwen minder vaak tot de gemengde groep wanneer de ouders lagere of middelbare employee zijn. Bij vrouwen hebben cognitieve kenmerken - in tegenstelling tot bij mannen - een significante invloed op de latere positie in de werkkring. Ten eerste hebben vrouwen met relatief goede schoolprestaties gedurende het laatste jaar van het basisonderwijs minder vaak een uitkering. Ten tweede hebben vrouwen met een laag schooladvies significant vaker geen inkomstenbron dan vrouwen met een hoog schooladvies, ook wanneer rekening wordt gehouden met het hoogst behaalde onderwijsniveau.

\section{Tabel 4-5}

Resultaten van de multinomiale logitanalyse van de positie in de werkkring van vrouwen $(\mathrm{N}=6.490)$ : logit-effecten (gestandaardiseerde effecten tussen haakjes)

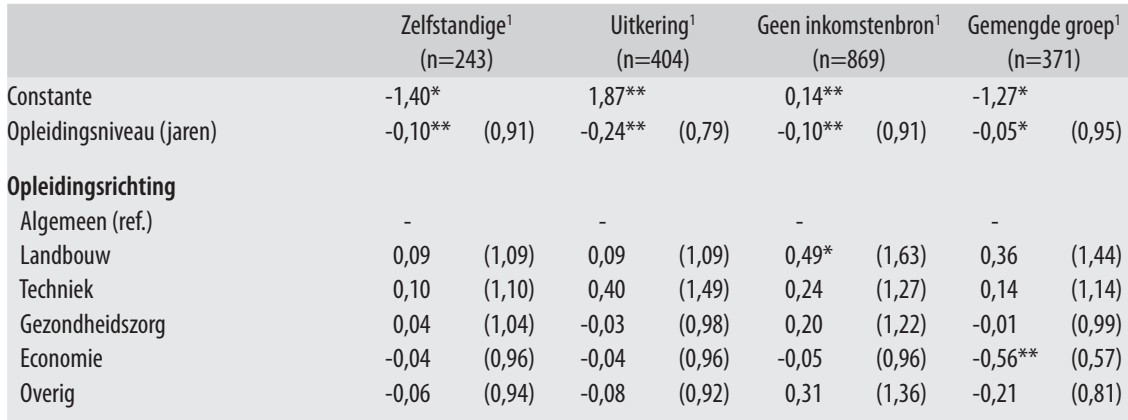

\section{Etniciteit}

Autochtoon (ref.)

Allochtoon

$-0,19$

$(0,83)$

$0,56^{* *}$

$(1,75)$

$-0,20$

$(0,82)$

0,23

Opleidingsniveau ouders

$-0,04$

$(0,96)$

$-0,05^{*}$

$(0,95)$

$-0,03$

$(0,97)$

$(1,02)$

Maatschappelijke positie ouders

Niet werkzaam (ref.)

Arbeider

Zelfstandige zonder personeel

$-0,21 \quad(0,81)$

$0,54 \quad(1,72)$

$-0,30^{*}$

$-0,47$

$1,07^{* *} \quad(2,91) \quad-0,42$

Zelfstandige met personeel

$-0,90 * * \quad(0,41)$

$-0,12$

Middelbare employee

$0,27 \quad(1,30)$

Hogere employee

0,13

$(1,14)$

$-0,31$

$-0,31$

$(0,74) \quad-0,01$

$(0,62) \quad-0,05$

$(0,99) \quad-0,23$

$(0,66) \quad 0,26$

$(0,95)$

$-0,13$

$(0,80)$

$(1,30) \quad 0,11 \quad(1,11)$

Leesgedrag leerling

$-0,12$

$(0,88)$

$(0,73)$

$-0,16$

$(0,86) \quad-0,50^{*}$

$(0,61)$

Onderwijsondersteunend thuisklimaat

0,11

$(1,12)$

0,06

$(0,73) \quad-0,12$

$(0,87) \quad-0,45^{*}$

$(0,64)$

Schoolprestaties

$0,41 \quad(1,50)$

$-0,34$

$(1,06) \quad 0,03$

$(0,88) \quad 0,21$

$(1,23)$

Non-verbale intelligentie

0,24

$(1,27)$

$-0,61^{*}$

$(0,71) \quad-0,27^{*}$

$(1,03) \quad-0,01$

$(0,99)$

Schooladvies

0,01

$(1,01)$

$-0,16$

$(0,55)$

$(0,77)$

$-0,16$

$(0,85)$

$(0,85) \quad 0,02 \quad(1,02)$

0,27

$(1,32)$

$-0,10$

$(0,91)$

$-0,19^{* *}$

$(0,83)$

$(1,09)$

Nagelkerke $\mathrm{R}^{2}$

${ }^{1}$ relatief ten opzichte van werknemer $(n=4.603) ;{ }^{*}=p<0,05 ;{ }^{* *}=p<0,01 ;$ ref. $=$ referentiecategorie

Bron: Schoolloopbaan en herkomst van leerlingen bij het voorgezet onderwijs (SLVO) 1982; Sociaal Statistisch Bestand (SSB), Centraal Bureau voor de Statistiek 
Naarmate het opleidingsniveau hoger is, neemt het inkomen toe. Voor mannen leidt ieder jaar extra scholing tot een gemiddelde stijging van het loon met $€$ 3,68 per dag (in het uiteindelijke model). Ook hier is de invloed van het behaalde opleidingsniveau voor vrouwen groter dan voor mannen. Eén jaar extra scholing betekent voor vrouwen een gemiddelde stijging van het loon met $€ 4,37$ per dag. Daarnaast is de gevolgde opleidingsrichting van invloed op het inkomen. Voor zowel mannen als vrouwen blijkt dat degenen met een opleiding in de richtingen landbouw, gezondheidszorg en overig relatief minder verdienen dan degenen met een algemene achtergrond. Wanneer men controleert voor cognitieve vaardigheden worden de verschillen in inkomen tussen de richtingen kleiner. De verschillen in inkomen tussen opleidingsrichting worden dus deels verklaard door verschillen in cognitieve vaardigheden. De keuze voor een opleidingsrichting hangt dus voor een belangrijk deel samen met cognitieve competenties.

Sociale herkomst blijkt van invloed te zijn op de latere inkomenspositie. Daarbij bestaan duidelijke verschillen tussen mannen en vrouwen. Voor mannen is de maatschappelijke positie van de ouders van belang voor het inkomen. Mannen met ouders die werkzaam zijn als zelfstandige met personeel, middelbare of hogere employee hebben een hoger inkomen dan mannen waarvan de ouders niet werkzaam zijn. Voor mannen van wie de ouders tot de hogere employees behoren, ligt het bruto inkomen per dag $€ 20,20$ hoger dan voor mannen waarvan de ouders niet werkzaam zijn. Opvallend in dit verband is dat de maatschappelijke positie van de ouders er bij vrouwen minder toe doet. Als de ouders tot de hogere employees behoren, verdienen vrouwen $€ 5,84$ meer dan vrouwen waarvan de ouders tot de niet-werkzamen behoren.

Bij vrouwen heeft, in tegenstelling tot mannen, juist het opleidingsniveau van de ouders een significante invloed op het inkomen. Vrouwen verdienen meer naarmate de ouders een hoger opleidingsniveau hebben behaald. Waarschijnlijk speelt hierbij mee dat hoog opgeleide moeders hun dochters meer stimuleren, en als voorbeeld dienen, dan laag opgeleide moeders. Wat opvalt, is dat er geen significante verschillen meer zijn tussen autochtonen en allochtonen wanneer gecontroleerd wordt voor hoogst behaald opleidingsniveau. Allochtonen verdienen even veel als autochtonen en dit geldt zowel voor mannen als voor vrouwen. Hierbij moet wel worden opgemerkt dat het in deze analyse alleen de werkenden betreft. Er heeft dus al een selectie plaatsgevonden op personen die inkomsten hebben uit werk. Bovendien is er geen onderscheid gemaakt naar de verschillende herkomstgroepen. Binnen de verschillende herkomstgroepen bestaan grote verschillen in arbeidsmarktsucces.

Cognitieve vaardigheden hebben naast een indirect effect - via het behaalde opleidingsniveau - ook nog een direct effect op de latere inkomenspositie. Daarbij geldt alléén voor vrouwen dat de schoolprestaties na controle voor het schooladvies een significante invloed hebben op het inkomen. Vrouwen met goede schoolprestaties hebben een hoger inkomen dan vrouwen met minder goede schoolprestaties. Voor mannen voegen de schoolprestaties aan het begin van de schoolloopbaan niets toe 
aan de arbeidsmarktkansen op de lange termijn wanneer gecontroleerd wordt voor het schooladvies. Een van de mogelijke verklaringen waarom schoolprestaties voor vrouwen een additioneel effect opleveren, is dat vrouwen die goed presteren op school ook in het latere werk vaak ambitieus en gemotiveerd zijn waardoor ze in betere banen terecht komen met hogere inkomens.

\section{Tabel 4-6}

Resultaten van de analyse van het gemiddeld inkomen per sv-dag (in euro's) van mannen: ongestandaardiseerde regressiecoëfficiënten (gestandaardiseerde effecten tussen haakjes)

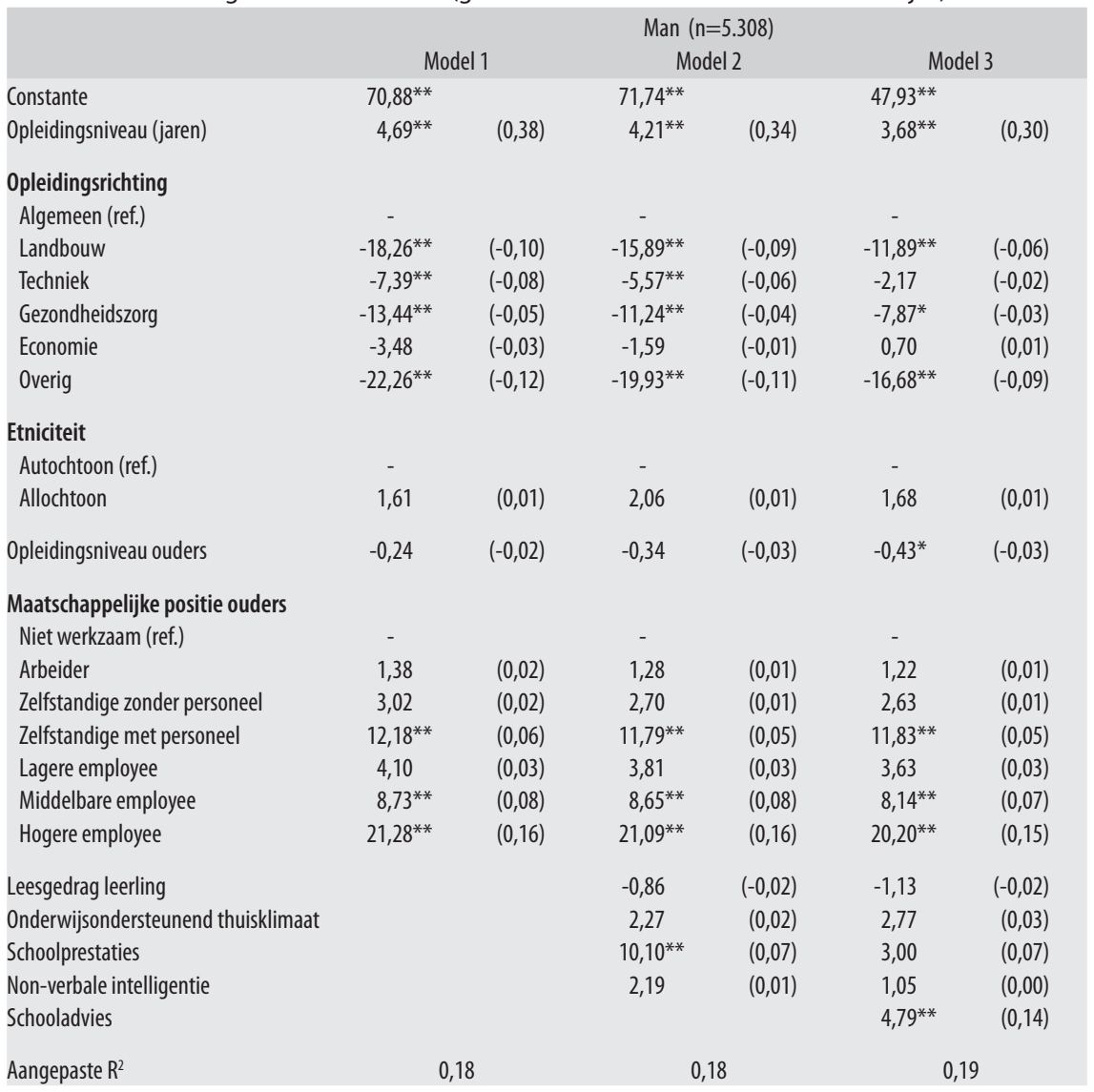

${ }^{*}=p<0,05 ;{ }^{* *}=p<0,01 ;$ ref. $=$ referentiecategorie

Bron: Schoolloopbaan en herkomst van leerlingen bij het voorgezet onderwijs (SLVO) 1982; Sociaal Statistisch Bestand (SSB), Centraal Bureau voor de Statistiek

Het schooladvies heeft zowel bij mannen als vrouwen een significant effect op het inkomen. Het blijkt dat degenen met een hoog schooladvies een hoger inkomen hebben dan degenen met een laag schooladvies. Opvallend is verder dat het onderwijsondersteunend thuisklimaat alléén bij vrouwen er toe doet. Het onderwijsondersteunend thuisklimaat heeft bij vrouwen een positieve invloed op het latere inkomen. 
Dit betekent voor vrouwen dat ze meer verdienen wanneer de ouders vaker met de kinderen hebben gesproken over school of vaker complimenten hebben gegeven over de schoolprestaties.

\section{Tabel 4-7}

Resultaten van de analyse van het gemiddeld inkomen per sv-dag (in euro's) van vrouwen: ongestandaardiseerde regressiecoëfficiënten (gestandaardiseerde effecten tussen haakjes)

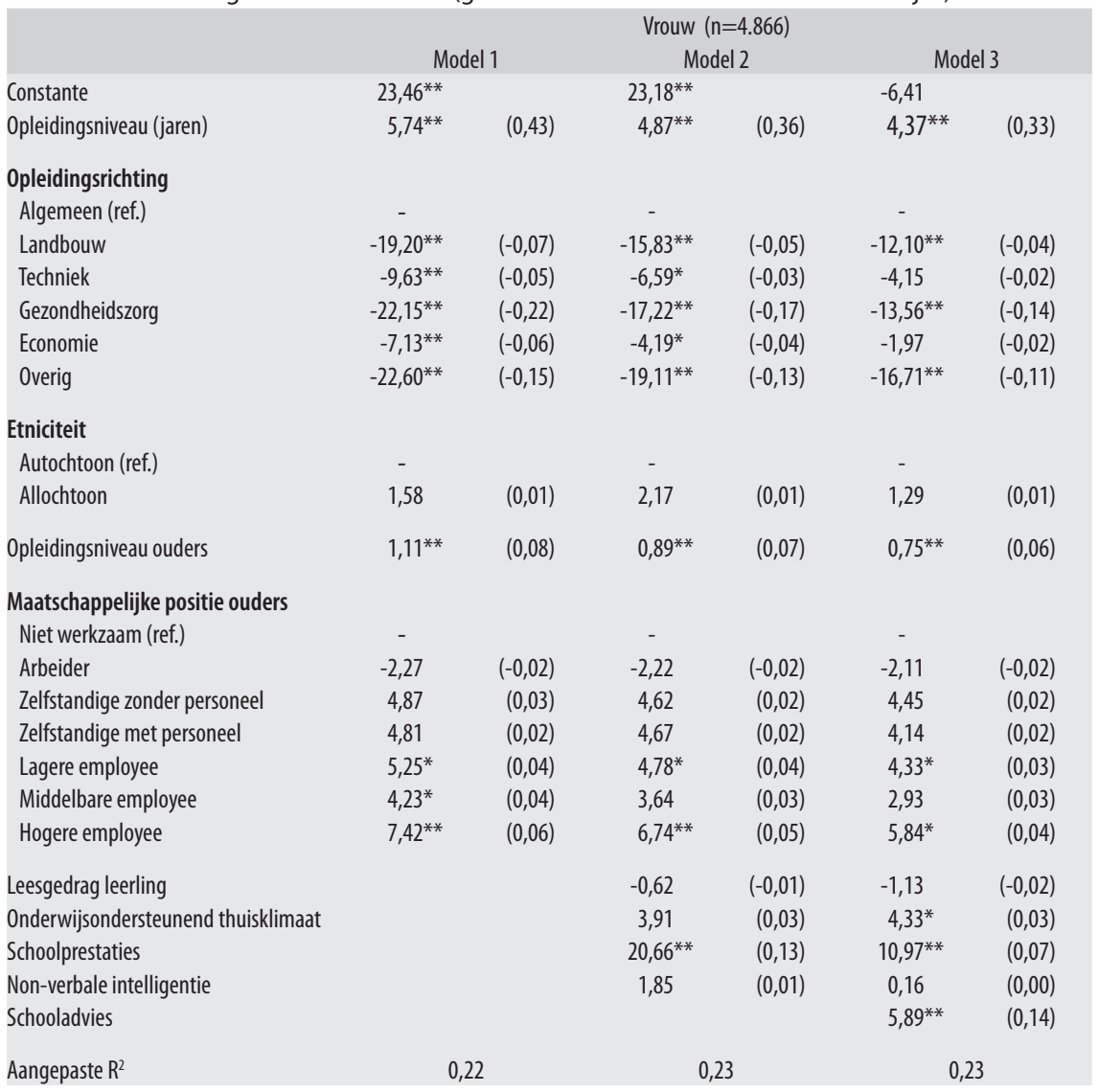

${ }^{*}=p<0,05 ;{ }^{* *}=p<0,01 ;$ ref. $=$ referentiecategorie

Bron: Schoolloopbaan en herkomst van leerlingen bij het voorgezet onderwijs (SLVO) 1982; Sociaal Statistisch Bestand (SSB), Centraal Bureau voor de Statistiek 



\section{Conclusie}

Omdat onderwijs een belangrijke rol speelt bij de positie die mensen weten te verwerven op de arbeidsmarkt, is het van belang beter inzicht te krijgen in de achterliggende factoren die verklaren waarom de gevolgde opleiding zo'n belangrijke voorspeller is voor het latere arbeidsmarktsucces. Veel van het bestaande onderzoek richt zich daarbij op de korte termijn effecten van het onderwijs; de effecten die zich openbaren tijdens de transitie van school naar werk. Het huidige onderzoek richt zich daarentegen op de lange termijn effecten van het onderwijs. Dit is uiteengelegd in de volgende drie onderzoeksvragen:

1. Wat zijn de lange termijn effecten van de gevolgde opleiding op de huidige arbeidsmarktpositie?

2. Wat is de invloed van sociale en culturele hulpbronnen op de bereikte arbeidsmarktpositie?

3. Wat is de invloed van cognitief vermogen op de bereikte arbeidsmarktpositie?

Om na te kunnen gaan in welke mate het hoogst behaalde opleidingsniveau van invloed is op de positie die mensen innemen op de arbeidsmarkt is gebruik gemaakt van de gegevens van een grootschalig onderwijscohort. Hiervoor is een koppeling gelegd tussen het SLVO, dat gestart is in 1982, en het Sociaal Statistische Bestand 2003. Het idee van het tot leven wekken van panels is niet nieuw. In het verleden zijn verschillende studies verricht waarbij vele jaren later mensen opnieuw werden benaderd. Door optimaal gebruik te maken van integrale informatie uit registers zijn wij echter gekomen tot een unieke dataset waarin over het algemeen betere metingen beschikbaar zijn van alle cruciale variabelen. Bovendien is de respons van de nieuwe dataset vele malen hoger doordat men niet meer afhankelijk is van de adresgegevens en bereidwilligheid van respondenten.

De resultaten van dit onderzoek hebben laten zien dat het succes op de arbeidsmarkt stijgt, naarmate het opleidingsniveau toeneemt. Personen met een hoog opleidingsniveau hebben vaker werk en minder vaak een uitkering dan degenen met een laag opleidingsniveau. Dit is wat men mag verwachten. Wat hierbij echter duidelijk naar voren is gekomen, is dat bij mannen vooral degenen met uitsluitend basisonderwijs de meest kwetsbare groep vormen. Mannen met alléén basisonderwijs hebben veruit het minst vaak werk en het vaakst een uitkering. De overige onderwijssoorten bieden op de lange termijn een relatief goede kans op werk. 
Bij vrouwen vormen degenen met uitsluitend basisonderwijs of een vвo-diploma de meest kwetsbare groep. Deze vrouwen hebben duidelijk minder vaak werk en vaker een uitkering dan vrouwen die een hoger opleidingsniveau hebben bereikt. Wat betreft het inkomen geldt dat dertigers doorgaans meer verdienen wanneer ze een hoger opleidingsniveau hebben bereikt. Wat hierbij opvalt is het verschil in inkomen tussen dertigers met een wo-diploma en dertigers met een ander diploma. Dertigers met een wo-dipoma verdienen naar verhouding veel meer dan andere dertigers.

Het opleidingsniveau dat mensen behalen wordt voor een groot deel bepaald door schoolprestaties, intelligentie en het schooladvies. Los van het opleidingsniveau hebben cognitieve vaardigheden ook zelf nog een direct effect op de arbeidsmarktpositie. Daarbij hebben schoolprestaties en schooladvies bij vrouwen een grotere invloed op het latere inkomen dan bij mannen. Bij het hebben van een baan en de positie in de werkkring zijn er echter nauwelijks effecten van cognitieve vaardigheden.

Ook sociale en culturele hulpbronnen hebben naast een indirect effect - via het behaalde opleidingsniveau - een direct effect op de latere arbeidsmarktpositie. Het effect van deze hulpbronnen is anders voor mannen dan voor vrouwen. Bij zowel mannen als vrouwen hangen sociale en culturele hulpbronnen positief samen met de kans op werk en het inkomen. Echter voor mannen verloopt dit via de maatschappelijke positie van de ouders, terwijl bij vrouwen juist het opleidingsniveau van de ouders van belang is.

Analoog aan het onderzoek naar korte termijneffecten (Traag et al., 2004), is in de analyses in dit rapport steeds uitsluitend rekening gehouden met kenmerken van personen die reeds aanwezig waren gedurende de schoolloopbaan. De verklaarde variantie van de modellen blijkt steeds relatief laag te zijn. Een groot deel van de variantie wordt dus niet verklaard door een combinatie van het opleidingsniveau en andere kenmerken uit het begin van de onderwijsloopbaan. Dit is niet verwonderlijk. Voor dertigers geldt dat er ondertussen meerdere transities in de levensloop hebben plaatsgevonden, die van invloed zijn op het arbeidsmarktsucces. Zo speelt het al dan niet hebben van een partner een rol, alsmede het inkomen van een eventuele partner. Ook het hebben van kinderen is, zeker voor vrouwen, van groot belang. Voor vervolgonderzoek zouden de gebruikte modellen dan ook uitgebreid moeten worden met kenmerken uit andere levensdomeinen. Dit is goed mogelijk door een verdere uitbreiding van het databestand met informatie over de burgerlijke staat, het hebben van kinderen, het inkomen van de eventuele partner etc. Op die manier kan een beter beeld geschetst worden van de opbrengsten van onderwijs op de lange termijn. 


\section{Literatuur}

Allen, J., Glebbeek, A. \& Van der Velden, R. (2000), Op naar een nieuwe mijlpaal: een conceptueel kader voor loopbaanonderzoek. ROA: Maastricht.

Bros, L. \& Dronkers, J. (1994), Jencks in Twente: over de sleutelmacht van het onderwijs en de arbeidsmarktpositie van vrouwen, Amsterdam Sociologisch Tijdschrift, 21, 67-88.

CBS (1987), Standaard Onderwijsindeling 1987, Den Haag: Centraal Bureau voor de Statistiek.

Collaris, J.W.M. \& Kropman, J.A. (1978), Van Jaar tot Jaar; een tweede fase: de wijze waarop secundair dagonderwijs doorlopen is, de eerste keuze na het verlaten daarvan, ITS: Nijmegen.

Diederen, J. (1991), Loopbaan tussen 25 en 35 jaar; Van Jaar tot Jaar, vierde fase: over de effecten van geslacht, milieu van herkomst, schoolprestaties, belangstelling en gevolgd onderwijs op beroepsloopbaan en levensloop, ITS: Nijmegen.

Dronkers, J. (1987), Ouders, liefde en geld; de relaties tussen ouderlijk milieu, schoolloopbaan, beroep, huwelijk en gezinsinkomen bij vrouwen. In: W. Meijnen, L. Nieuwenhuis \& J. Peschar (red.), Selectie en kwalificatie in het onderwijs (pp. 121-136), Lisse: Swets en Zeitlinger.

Dronkers, J. \& Bakker, B. (1986), Van het dubbeltje en het kwartje; een studie naar de relatie tussen milieu, onderwijs, partnerkeuze, beroep en gezin, Economisch Statistische Berichten, 71, 1184-1189.

Dronkers, J. \& De Jong, U. (1978), Jencks en Fagerlind op zijn Hollands; een aanzet tot de studie van de relaties tussen milieu, intelligentie, onderwijs, beroep en inkomen, Sociologische Gids, 25, 4-30.

Hartog, J. \& Pfann, G. (1985), Vervolgonderzoek Noord-Brabantse zesdeklassers, UVA: Amsterdam.

Meesters, M.J., Dronkers, J. \& Schijf, H. (1983), Veranderende onderwijskans? Een derde voorbeeld en afrondende conclusies, Mens en Maatschappij, 58, pp. 5-27.

Meesters, M.J. (1992). Loopbanen in het onderwijs en op de arbeidsmarkt. ITS: Nijmegen.

Traag, T., Van der Valk, J., Van der Velden, R., De Vries, R. \& Wolbers, M. (2004), Leren Loont! De overgang van school naar werk voor leerlingen van het VOCL '89, ROA-R-2004/6, Maastricht: ROA/CBS.

Velden, R. van der \& Van Smoorenburg, M. (1999), 'Overscholing en beloning: Het effect van verschillende meetmethoden', Tijdschrift voor Arbeidsvraagstukken 15-2, 111-123. 



\section{Bijlage 1 Selectiviteit van de koppeling}

Tabel 1

Verdeling onderzoekspopulatie naar geslacht

$\begin{array}{lccc} & \text { Gekoppeld } & \text { Niet gekoppeld } & \text { Totaal } \\ \text { Jongens } & 49,7 & 50,6 & 49,8 \\ \text { Meisjes } & 50,3 & 49,4 & 50,2 \\ \mathrm{~N} & 14.695 & 2.118 & 16.813 \\ \times^{2} & & 0,00 & \end{array}$

${ }^{*}=p<0,05 ;{ }^{* *}=p<0,01$; ref. $=$ referentiecategorie

Bron: Schoolloopbaan en herkomst van leerlingen bij het voorgezet onderwijs (SLVO) 1982; Sociaal Statistisch Bestand (SSB), Centraal Bureau voor de Statistiek

\section{Tabel 2}

Verdeling onderzoekspopulatie naar schooladvies

$\begin{array}{lccc} & \text { Gekoppeld } & \text { Niet gekoppeld } & \text { Totaal } \\ \text { Gemiddelde advies } & 7,19 & 7,17 & 7,19 \\ \text { N } & 14.469 & 2.064 & 16.533 \\ \text { F } & & 0,65 & \end{array}$

${ }^{*}=\mathrm{p}<0,05 ;{ }^{* *}=\mathrm{p}<0,01 ;$ ref. $=$ referentiecategorie

Bron: Schoolloopbaan en herkomst van leerlingen bij het voorgezet onderwijs (SLVO) 1982; Sociaal Statistisch Bestand (SSB), Centraal Bureau voor de Statistiek

Tabel 3

Verdeling onderzoekspopulatie naar hoogst behaald onderwijsniveau

$\begin{array}{lccc} & \text { Gekoppeld } & \text { Niet gekoppeld } & \text { Totaal } \\ \text { Basisonderwijs } & 11,1 & 20,3 & 12,2 \\ \text { Mavo } & 12,3 & 11,9 & 12,2 \\ \text { Vbo } & 20,4 & 19,2 & 20,2 \\ \text { Havo } & 7,4 & 7,2 & 7,4 \\ \text { Vwo } & 4,4 & 5,0 & 4,5 \\ \text { Mbo } & 25,4 & 19,7 & 24,7 \\ \text { Hbo } & 12,7 & 11,2 & 12,5 \\ \text { Wo } & 6,3 & 5,6 & 6,2 \\ \text { Totaal } & 14.695 & 2.118 & 16.813 \\ \times^{2} & & 0,12 & \end{array}$

${ }^{*}=\mathrm{p}<0,05 ;{ }^{* *}=\mathrm{p}<0,01$

Bron: Schoolloopbaan en herkomst van leerlingen bij het voorgezet onderwijs (SLVO) 1982; Sociaal Statistisch Bestand (SSB), Centraal Bureau voor de Statistiek 


\section{Tabel 4}

Verdeling onderzoekspopulatie naar sociaal milieu

$\begin{array}{lccc} & \text { Gekoppeld } & \text { Niet gekoppeld } & \text { Totaal } \\ \text { Arbeider } & 29,1 & 26,1 & 28,7 \\ \text { Zelfstandige zonder personeel } & 5,8 & 4,5 & 5,7 \\ \text { Zelfstandige met personeel } & 4,3 & 4,7 & 4,4 \\ \text { Lagere employée } & 10,9 & 9,8 & 10,8 \\ \text { Middelbare employée } & 16,6 & 15,2 & 16,4 \\ \text { Hogere employée } & 10,6 & 11,5 & 10,7 \\ \text { Overig en onbekend } & 22,6 & 28,2 & 23,3 \\ \text { Totaal } & 16.495 & 2.118 & 16.813 \\ x^{2} & & 0,02 & \end{array}$

$*=p<0,05 ;{ }^{* *}=p<0,01$

Bron: Schoolloopbaan en herkomst van leerlingen bij het voorgezet onderwijs (SLVO) 1982; Sociaal Statistisch Bestand (SSB), Centraal Bureau voor de Statistiek

\section{Tabel 5}

Verdeling onderzoekspopulatie naar opleidingsniveau vader

$\begin{array}{lccc} & \text { Gekoppeld } & \text { Niet gekoppeld } & \text { Totaal } \\ \text { Lager onderwijs } & 31,3 & 31,1 & 31,3 \\ \text { Beroepsonderwijs-niveau 1 } & 21,0 & 16,4 & 20,4 \\ \text { Beroepsonderwijs-niveau 2 } & 8,0 & 6,2 & 7,8 \\ \text { Algemeen onderwijs-niveau 1 } & 9,1 & 8,0 & 9,0 \\ \text { Algemeen onderwijs-niveau 2 } & 2,9 & 3,7 & 3,0 \\ \text { Hoger beroepsonderwijs } & 8,3 & 8,8 & 8,4 \\ \text { Kandidaatsopleiding } & 1,1 & 1,4 & 1,1 \\ \text { Doctoraalopleiding } & 3,2 & 3,9 & 3,3 \\ \text { Onbekend } & 15,1 & 20,5 & 15,7 \\ \text { Totaal } & 14.695 & 2.118 & 16.813 \\ \times^{2} & & 0,04 & \end{array}$

$*=p<0,05 ; *$ * $p<0,01$

Bron: Schoolloopbaan en herkomst van leerlingen bij het voorgezet onderwijs (SLVO) 1982; Sociaal Statistisch Bestand (SSB), Centraal Bureau voor de Statistiek

\section{Tabel 6}

Verdeling onderzoekspopulatie naar opleidingsniveau moeder

$\begin{array}{lccc} & \text { Gekoppeld } & \text { Niet gekoppeld } & \text { Totaal } \\ \text { Lager onderwijs } & 39,2 & 39,5 & 39,3 \\ \text { Beroepsonderwijs-niveau 1 } & 18,9 & 15,9 & 18,5 \\ \text { Beroepsonderwijs-niveau 2 } & 11,8 & 11,4 & 11,7 \\ \text { Algemeen onderwijs-niveau 1 } & 11,2 & 10,5 & 11,1 \\ \text { Algemeen onderwijs-niveau 2 } & 2,6 & 3,5 & 2,7 \\ \text { Hoger beroepsonderwijs } & 4,0 & 4,7 & 4,1 \\ \text { Kandidaatsopleiding } & 0,4 & 0,5 & 0,4 \\ \text { Doctoraalopleiding } & 0,5 & 0,6 & 0,5 \\ \text { Onbekend } & 11,4 & 13,4 & 11,7 \\ \text { Totaal } & 14.695 & 2.118 & 16.813 \\ x^{2} & & 0,01 & \end{array}$

* $=\mathrm{p}<0,05{ }^{* *}=\mathrm{p}<0,01$

Bron: Schoolloopbaan en herkomst van leerlingen bij het voorgezet onderwijs (SLVO) 1982; Sociaal Statistisch Bestand (SSB), Centraal Bureau voor de Statistiek 


\section{Bijlage 2 \\ Operationalisering van de variabelen}

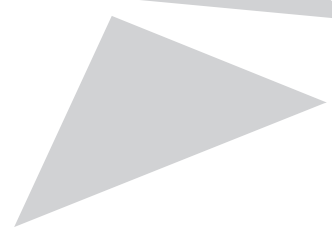

In deze bijlage wordt per variabele besproken hoe de variabelen zijn geoperationaliseerd.

- Het hoogst bereikte opleidingsniveau is gemeten aan de hand van het aantal benodigde jaren scholing om dit niveau te bereiken. Uitgangspunt voor deze berekening is de leerweg die loopt via de beroepsopleidingen (Van der Velden \& van Smoorenburg, 1999). De volgende waarden zijn toegekend: 6 jaren (во), Iо jaren (LBO), II jaren (MAVO), I2 jaren (КМво), I3 jaren (HAVO), I4 jaren (Мво), I5 jaren (vwo), I7 jaren (нво) en I9 jaren (wo).

- De opleidingsrichting van het hoogst bereikte opleidingsniveau is ingedeeld in zes categorieën, te weten: I) algemeen, 2) landbouw, 3) techniek, 4) economie 5) gezondheidszorg en 6) overig. Degenen die basisonderwijs, MAvo, Havo of vwo als hoogst behaalde opleiding hebben behaald, worden gerekend tot de categorie 'algemeen'.

- Een allochtoon is ofwel iemand die in het buitenland is geboren of iemand van wie een van beide ouders in het buitenland is geboren. Landen die als buitenland worden angemerkt, staan vermeld in de Wet Stimulering Arbeidsdeelname Minderheden (samen).

- Schoolprestaties zijn gebaseerd op de totaalscore op drie toetsen (Nederlands, rekenen en informatieverwerking), die met behulp van een door het CITO samengestelde versie van de Entreetoets halverwege het laatste jaar van het basisonderwijs zijn afgenomen. De toetsen omvatten ieder 20 multiple choicevragen. De totaalscore is uitgedrukt op een schaal lopend van o tot en met I.

- Non-verbale intelligentie is vastgesteld door een tweetal toetsen, die beiden in het laatste jaar van het basisonderwijs zijn afgenomen. De eerste subtest (PSB3) meet het redeneervermogen; de tweede subtest (PSB-8) het abstractievermogen. Beide subtesten bestaan uit 40 items. Van beide subtesten is het aantal correcte items gesommeerd. Deze somscore is vervolgens getransformeerd naar een schaal met een minimale waarde van o en een maximale waarde van I.

- Het schooladvies is gebaseerd op het advies dat de leerling van de basisschool heeft gekregen met betrekking tot de doorstroom naar het voortgezet onderwijs. Dit advies bestaat uit acht opleidingscategorieën, variërend van BUO/IBO tot en met vwo. Deze zijn gecodeerd volgens de leerjarenladder: $\mathrm{BUO} / \mathrm{IBO}=5$, $\mathrm{LBO} / \mathrm{VBO}=6, \mathrm{MAVO} /$ middenschool $=7, \mathrm{HAVO}=8, \mathrm{VWO}=9$. Leerlingen met een gemengd advies hebben een gemiddelde waarde gekregen. 
- De sociale herkomst van de leerlingen is bepaald aan de hand van twee indicatoren, te weten het opleidingsniveau van de ouders en de maatschappelijke positie van de ouders. Deze zijn verzameld via de oudervragenlijst die in het laatste jaar van het basisonderwijs bij de ouders is afgenomen. Het bepalen van het opleidingsniveau van de ouders heeft plaatsgevonden op basis van de niveau-indeling van de Standaard Onderwijsindeling 1978 (sor'78) (CBS, 1987). Daarbij is uitgegaan van het gemiddelde opleidingsniveau van (een van) beide ouders. De verschillende niveaus zijn vervolgens omgerekend naar het gemiddelde aantal jaren nominale scholing. Dit levert de volgende waarden op: 6 jaren (lager onderwijs), Io jaren (voortgezet onderwijs, lager trap), I4 jaren (voortgezet onderwijs, hogere trap), I7 jaren (hoger onderwijs, eerste fase) en I9 jaren (hoger onderwijs, tweede fase). De maatschappelijke positie van de ouders is gebaseerd op informatie over de werkzaamheid en het beroep van de hoofdkostwinner van het gezin. De volgende categorieën zijn onderscheiden: I) niet werkzaam, 2) arbeider, 3), zelfstandige zonder personeel, 4) zelfstandige met personeel, 5) lagere employee, 6) middelbare employee en 7) hogere employee.

- Het leesgedrag van de leerling is ook verzameld via de oudervragenlijst. Aan de ouders is gevraagd hoeveel tijd de leerling gemiddeld per week leest als het gaat om boeken en kranten. Er worden vijf categorieën onderscheiden: I) bijna nooit, 2) minder dan twee uren, 3) twee tot vijf uren, 4) vijf tot tien uren en 5) meer dan tien uren.

- Het onderwijsondersteunend thuisklimaat is gebaseerd op vragen aan beide ouders over het hebben van gesprekken over school, het hebben van gesprekken over prestaties en het geven van complimenten over schoolprestaties. Deze vragen zijn gesteld in de oudervragenlijst. Deze items zijn samengevoegd tot een schaal met een Cronbach's alpha van o,6r. De minimale waarde van deze schaal is o; de maximale $\mathrm{I}$.

- De positie in de werkkring en de kans op een baan zijn gebaseerd op informatie uit het SSB voor 2003. De positie in de werkkring is onderverdeeld in vijf categorieën, namelijk I) werknemer, 2) zelfstandige, 3) uitkering, 4) geen inkomensbron en 5) gemengde groep. Onder uitkeringen vallen arbeidsongeschiktheidsuitkeringen, werkloosheidsuitkeringen, bijstands-uitkeringen, uitkeringen IOAW/IOAZ en overige uitkeringen (hieronder vallen alle niet eerder genoemde uitkeringen, waaronder uitkeringen in het kader van de ziektewet en de wachtgeldregeling in de overheid). De gemengde groep bestaat uit degenen met een combinatie van werknemer en zelfstandige, werknemer en uitkering, zelfstandige en uitkering of werknemer, zelfstandige en uitkering (inclusief pensioen). De kans op een baan maakt onderscheid tussen personen met tenminste één baan en personen zonder baan. Personen met de arbeidspositie werknemer, zelfstandige of die behoren tot de gemengde groep worden gerekend tot de degenen met tenminste één baan. Personen met de arbeidspositie uitkering behoren tot degenen zonder een baan. 
- De beloning is gebaseerd op het gemiddeld inkomen per sociale verzekeringsdag in 2003 (ook afkomstig uit het SSB). Hiervoor is het bruto jaarloon sociale verzekering voor 2003 gedeeld door het aantal sociale verzekeringsdagen in 2003. Het bruto loon sociale verzekering is het loon waarover premieheffing voor de werknemersverzekeringen plaats vindt. De sociale verzekeringsdagen (sv-dagen) zijn het aantal werkdagen waarover premieheffing voor de werknemersverzekeringen plaats vindt. Ook als slechts één uur op een dag wordt gewerkt, wordt deze dag als één sv-dag meegeteld. Bij de bepaling van de beloning zijn zelfstandigen niet meegenomen. 
